\title{
Einstein, cientista e filósofo?
}

\section{MICHEL PATY}

\section{$\mathrm{P}$}

arece findo o tempo no qual os cientistas eram também filósofos, ou o inverso. A época náo é mais dos Descartes e dos Leibniz. Já a filosofia natural de Newton inclina-se decididamente para o lado científico; mas devemos reconhecer que Newton colocou conceitos que alimentaram de forma duradoura as filosofias dos séculos seguintes (o tempo, o espaço, a causalidade) e regras de metodologia científica que servem em parte, ainda hoje, de referência.

Em seguida a clivagem ocorre de forma mais brutal e parece que se pode, daí em diante, classificar os pensadores em categorias separadas e mesmo, logo depois, estanques. No século XVIII d'Alembert figura como exceçáo, embora ainda seja muito pouco considerado como um filósofo importante. Já no século XIX nós enumeramos muitos casos de cientistas-filósofos nos diversos ramos da ciência; da lógica com Bolzano ou Frege e da matemática de Riemann a Clifford, Peano ou Poincaré, às ciências naturais em transformaçáo e sem falar nas ciências sociais nascentes ainda estreitamente ligadas à terra mãe da filosofia. Para nos restringir à física e aos físicos ou físico-matemáticos mais notórios, Ampère, von Helmholtz, Kirchhoff, Hertz, Boltzmann, Mach, Poincaré de novo e Duhem respondem a esta qualificaçáo.

Mas são estes cientistas realmente considerados como filósofos no sentido pleno? Eles mesmos não o reivindicaram, porque tinham consciência da clivagem. De seu lado, os filósofos que se interessam pelo pensamento destes cientistas se satisfazem em geral com as partes filosóficas destas obras que lhes dizem respeito diretamente, à medida em que elas podem contribuir para instruir seus próprios debates. Raramente preocupam-se com a relação entre estes escritos epistemológicos ou filosóficos e o trabalho científico que os acompanha. Sobre o pensamento destes cientistas-filósofos pesa, em geral, a suspeição de não ser nem sistemático nem de alcance suficientemente geral; e de demonstrar excessiva precisão em suas análises das proposições da ciência. Em suma, estes pensadores não caracterizaram suficientemente a divisão do trabalho entre o filósofo e o sábio (1) (ou, mais modestamente, o cientista, como dizemos hoje). 
O século XX conta igualmente com cientistas preocupados com a filosofia e, dentre eles, Einstein. Diferentemente dos pensadores precedentes, porém, não são tanto suas concepçóes epistemológicas que retêm de sua contribuição às idéias filosóficas, mas certas implicaçóes de sua própria obra científica considerada sobretudo sob o aspecto das novas concepçōes do espaço e do tempo, e da causalidade relativística.

Sobre a filosofia propriamente dita de Einstein, existe uma opiniáo corrente, formada sobre um conhecimento indireto e vago de seu pensamento, que lhe atribui todas as características do ecletismo. Isto é acentuado na França, onde a filosofia esteve largamente afastada, desde a segunda guerra mundial, da ciência e de seus problemas. Ele é reconhecido, nos meios melhor informados, como cientista-filosofo (aliás um livro com este título foi publicado em 1949, sob a forma de uma coletânea de contribuiçóes de cientistas e filósofos a propósito de Einstein $\mathrm{e}$, em alguns casos, dialogando com ele) (2). Mas alguns, duvidando que seu pensamento filosófico tenha sido sempre coerente (ele teria feito, segundo Holton (3), de sua juventude à maturidade uma verdadeira peregrinação filosófica através das posiçóes as mais variadas, do positivismo ao realismo e do empirismo ao racionalismo), chegam a afirmar que ele professava um oportunismo epistemológico (4) e entáo deve-se compreender filosófico, segundo o qual todas as concepçóes são válidas, ao menos no que diz respeito à sua relação com as ciências.

\section{A relação entre pensamento científico e pensamento filosófico}

\section{Uma obra cientifica de alcance filosófico}

O que impressiona na obra de Einstein, a ponto de ocultar os outros aspectos de seu pensamento, é o alcance considerável das modificações que ela causou nas visóes que tanto cientistas como filósofos estavam acostumados a ter. Mais que seu pensamento propriamente dito, foi sobretudo o conteúdo científico de sua obra que prendeu a atenção. Caso excepcional entre os cientistas-filosofos, ele náo interessava aos filósofos profissionais pelo que escreveu mas pelo que fez: ele thes teria entregue, de todo modo, o material bruto de conceitos e teorias novas, do qual estavam eles a decifrar a significaçáo profunda.

Não há dúvida que os temas filosóficos ligados às transformaçōes da física - como de toda ciência - escapam aos primeiros atores para desenhar um espaço que lhes é próprio, e no qual se exerce livremente a reflexão crítica. Mas o próprio pensamento do criador tem um interesse não menor, e talvez um interesse muito particular para os olhos do 
filósofo, pois aquele soube, qualquer que tenha sido a maneira, e cons- ${ }^{l}$ cientemente, ou náo - trazer à luz objetos de pensamento táo ricos de implicaçóes. Por esta razáo provavelmente, os autores do Manifesto do Ctrculo de Viena mencionam em variadas ocasióes, entre os inspiradores e os representantes do movimento que eles querem promover, o nome de Einstein. Mas, precisamente o Círculo em suas origens reivindicava para seus membros a condição de náo serem filosofos e de terem trabalhado em um ou outro dos domínios da ciência. E proclamava, por outro lado; afirmando a necessidade de pesquisas filosóficas sobre os fundamentos, que "não há filosofia como ciência fundamental e universal, ao lado ou, acima dos diferentes domínios da única ciência da expériência". Os escritos epistemológicos do cientista citados pelo Manifesto são pouco numerosos - e vão até 1921 - mas é afirmado, com precisão e de maneira significativa, que "importantes consideraçóes filosóficas se encontram igualmente nos trabalhos originais de Einstein" (5) (esta última observaçáo nos aproxima da perspectiva que queremos apresentar).

Pela estatura dề sua obra e por sua situação na história do desenvolvimento das idéias, Einstein ocupa um lugar privilegiado que o impõe à atenção do filósọofo. Mas, através e para além dele, são as ciências contemporâneas em seu conjunto, por seus conteúdos, suas modalidades, e pelo papel a que se vêem destinadas no campo social, que parecem determinar uma nova relaçáo com a filosofia. Com frequência as transformaçōes nas representaçóes e teorias científicas pareceram implicar mudanças de alto a baixo nas nossas concepçóes sobre o conhecimento, em sua natureza e condiçóes de possibilidade. As redistribuiçóes de questóes tradicionalmente consideradas como sendo de natureza filosófica parecem responder, não só como eco mas como conseqüência em profundidade, às crises sofridas pelos conhecimentos positipos, sejam das ciências formais (ver a questão dos fundamentos da matemática), ou da natureza (física, biologia), ou relativas às ciências humanas $\mathrm{e}$ sociais (das quais este século registra o crescimento).

Com relação a este estado de coisas, o caso do pensamento e da obra de Einstein não é único, mas exemplar e significativo. Ele é igualmente particular, e nós evitaremos, com todo o cuidado, erigir em conclusōes universais os elementos de significação que poderemos nele encontrar. A questão preliminar que se encontra colocada desde o início no nosso estudo é a da relação entre ciência e filosofia na formulação e soluçáo de problemas colocados por uma dada ciência, seja considerando estes problemas em si mesmos, tal como eles são postos ao exame de cada um, ou o caminho particular adotado por um criador individual na sua abordagem. 
A mais próxima corrente filosófica: o Círculo de Viena ?

A perspectiva adotada a este propósito por um movimento de pensamento como o Círculo de Viena, e seus próximos, pode aqui nos servir, provisoriamente, de fio condutor. $A$ anexaçăo - muito relativa - de Einstein pelo Círculo não o faz um adepto mesmo que momentâneo. Mas se é preciso designar, nos debates de idéias que acompanharam as renovaçóes da física, uma corrente que seria mais próxima que outras da atitude de Einstein - senão do conteúdo preciso de seu pensamento-, por suas intenções gerais, a escolha dirigir-se-ia de bom grado para aquela reunida em torno dos Círculos de Viena e de Berlim.

Moritz Schlick, animador do primeiro, foi, aliás, quem propôs (bem antes da constituição do Círculo) logo após a publicação dos trabalhos que estabeleciam a teoria da Relatividade geral, a crítica, fundada nesta teoria, do a priori kantiano. Crítica retomada e desenvolvida notadamente por Hans Reichenbach - figura de proa do segundo. E Schlick teve certamente influência, à época, sobre a evoluçáo das concepçóes epistemológicas de Einstein, como testemunha sua correspondência (6); não poderíamos falar de uma influência semelhante de Reichenbach apesar de o último ter mantido com Einstein seguidos intercâmbios filosóficos desde seu período comum em Berlim, até suas últimas conversaçóes em Princeton (7).

É um traço do perfil intelectual de Einstein ter, ao longo de sua vida, dialogado com filósofos contemporâneos ou do passado, através de intercâmbios diretos ou de leituras. Desde seu período de formaçăo ele leu, e mais tarde releu, Kant (este muito cedo, ao que parece com a idade de dezesseis anos), Hume, Mill, Mach, Poincaré e os cientistasfilósofos já citados, mas também Schopenhauer, que invocava de bom grado e, sobretudo, Spinoza, do qual ele se sentia tão próximo. Isto posto, é antes de tudo à própria filosofia de Einstein, considerada em seu movimento e sua estrutura, que nós nos prenderemos.

Einstein, o cientista, pode ser igualmente considerado como filósofo? E, em caso afirmativo, quais liçóes podemos disto extrair para a filosofia em sua relação com as ciências? Mais precisamente: que espécie de questôes filosóficas encontramos estudando um pensamento científico criador? Tal é, de fato, a questáo que nós nos esforçaremos para responder nesta obra: admitiremos, preliminarmente à questáo colocada nestes termos, que as ciências e a filosofia estăo, por sua natureza, em uma relação estreita e que, sem se confundir, elas podem se encontrar aplicadas à consideraçáo de objetos comuns. Esta solidariedade da ciência com a filosofia, afirmada anteriormente com força pelos filósofos das 
Luzes, ao mesmo tempo que estes reavaliavam as relaçôes anteriores sobre tal questão, parecia, à primeira vista, ter sido afirmada com uma força comparável, em nosso tempo, pelos adeptos do movimento da concepgráo cientifica do mundo promovido pelos Círculos de Viena e de Berlim (8) - os quais, aliás, se reclamavam herdeiros das Luzes. Nisto, ao menos, eles podiam invocar sem abuso a companhia de Einstein; ao que se junta a influência imediata de sua obra sobre eles.

Mas não era da natureza de Einstein deixar-se alistar por um movimento, qualquer que fosse, mesmo que, em geral, ele não tomasse o cuidado de reafirmar sua independência ou desacordo eventual por ocasiáo de tal anexaçáo ou interpretação. Muitos aspectos o separavam do positivismo e do empirismo lógico. Se o Wiener Kreis escolheu Einstein um dos três mentores e representantes oficiais e ativos da concepgão cientifica do mundo, com Russell e Wittgenstein, o fez sob o título de físico. Na tríade é, com efeito, a Russell e a Wittgenstein que é atribuído o papel de inspiradores filosóficos, um relativamente à lógica, o outro à linguagem - e são estes dois aspectos que determinam, como o sabemos, a orientação da nova filosofia. A Einstein é expressamente atribuído o papel de inspirador científico (pela física e geometria), e seu pensamento é requisitado à medida em que elaborou uma obra de alcance fundamental em física. De resto, pouco tempo depois, a orientaçáo filosófica do movimento iria se enrijecer, e uma nova diferenciação das tarefas entre o cientista e o filósofo se instituir, finalizando com a abertura afirmada precedentemente.

\section{"Filósofo por implicação ?"}

Em sua obra de 1951, $O$ adpento da filosofia cientifica, Reichenbach expóe como, depois do fim da filosofia dos sistemas cujo último representante verdadeiro foi o kantismo, ocorreu o nascimento de uma outra filosofia, oriunda do terreno de uma ciência nova, aparecida no século XVIII nas matemáticas, na física e na biologia, e elaborada de início pelos cientistas como subproduto de suas pesquisas científicas. É entáo, a seu ver, que ciência e filosofia se reencontraram a ponto de se confundir, pela necessidade, de certo modo, do momento histórico. "O matemático, o físico ou o biólogo", escreve ele, "buscando resolver os problemas técnicos de sua ciência, se via na incapacidade de encontrar uma soluçáo a não ser que respondesse a certas questóes mais gerais e filosóficas." Como não eram filósofos, estes cientistas não estavam, em absoluto, embaraçados nos sistemas e, "arrastados pela lógica dos problemas", eles puderam assim encontrar respostas "das quais não se tinha jamais ouvido falar na história da filosofia". 
Tal foi, segundo Reichenbach, a implicaçăo da ciência na filosofia para os tempos modernos: ela assegurou a possibilidade de fazer nascer uma nova filosofia. "Com o quadro (9) das respostas científicas às questóes filosóficas", prossegue ele, "é uma nova filosofia que se encontra desenhada, um sistema filosb́fico năo mais no sentido de uma criaçáo especulativa feita fantasiosamente por um pensamento, mas no sentido de uma totalidade ordenada à qual só um trabalho de grupo pode chegar" (10).

Contudo, uma vez realizada para a filosofia, esta passagem de uma era à outra, de uma concepçáo à outra, vem um estágio no qual o trabalho a ela concernente deve ser efetuado para ela mesma, por ela mes$\mathrm{ma}$, independentemente do trabalho científico, por novos profissionais da filosofia. Mas, sendo instaurada esta nova época da filosofia, o problema da relaçáo desta com a ciência não se encontra colocado, desde entáo, em termos semelhantes, no final das contas, àqueles do período findo? Em particular, a questão do aspecto filosófico de uma obra científica como aquela de Einstein não perde doravante - ou de novo todo interesse? A revoluçáo filosófica teria feito tábula rasa do passado e das próprias circunstâncias que presidiram seu advento.

Reichenbach admite, é certo, que o processo pode se reproduzir. "Parece", escreve ele a propósito da física em um outro texto da mesma época, "ser uma lei geral que fazer uma nova física precede uma nova filosofia da física"; e "a evoluçáo das idéias filosóficas é guiada por aquela das teorias físicas" (11). Mas seriam apenas tantos reajustamentos periódicos deixando intocado o problema de uma verdadeira dinâmica das relaçóes da ciência com a filosofia, destinadas a saltos bruscos resultando de implicaçăo nova, seguida de separação radical.

Reichenbach nos confirma assim que, fazendo obra cientifica, os cientistas da época a que se refere, fizeram, por isto, e nisto mesmo, obra de filósofos. Mas não era isto feito ao simples título de subproduto, como ele o diz? E se, longe de se encontrar restrita a um momento histórico ocasional (portanto comprometida a caducar, para a filosofia no sentido de Reichenbach, que quer ignorar deliberadamente a história), esta dimensão filosófica era inerente ao próprio trabalho de pesquisa cientifica, consubstancial a ele, por assim dizer, em numerosas circunstâncias senăo em todas, que ultrapassam, por sua significaçăo, 0 caso descrito como sendo exceçáo? Nós não nos decidiremos agora sobre isto, mas vemos bem como a resposta formulada por Reichenbach e os defensores do positivismo e do empirismo lógico permanece tributária dos limites de seu sistema. 
Em sua contribuiçăo à obra coletiva Einstein cientista e filósofo, Reichenbach prende-se ao caso particular deste cientista e se interroga sobre o fato de saber se ele era realmente filósofo e em quê. Sublinha de início que "a significação filosófica da teoria da relatividade"(12) não é suficiente para fazer de seu inventor um filósofo, pelo menos quanto à sua intenção inicial, pois que "seus primeiros objetivos se encontravam todos no domínio da física". É com vistas a resolver problemas físicos que o cientista se dirigiu para questóes filosóficas: o físico, no caso em tela, só tornou-se filósofo devido à ocasiāo, porque os problemas físicos que ele se colocava requeriam uma análise lógica de certos conceitos, o que gerava consequiências sobre a teoria do conhecimento. Avaliamos desde já os limites da implicação segundo esta visão: ela é restrita, com respeito à análise dos conceitos, aos aspectos fundamentais do espafo e do tempo, e inclinada de maneira unilateral e forçada para uma determinada filosofia, pois o reajustamentqque esta análise pressupóe consiste, segundo Reichenbach, em adotar a "teoria verificacionista da significaçáo" (13), isto quer dizer: "uma filosofia para a qual um enunciado é redutível à possibilidade de sua verificaçáo" (experimental ou observacional).

A Relatividade restrita é, segundo uma interpretação difundida tanto entre filósofos quanto entre os físicos que elaboraram a mecânica quântica no fim dos anos vinte, apenas uma conseqüência da necessidade de pensar os conceitos de espaço e de tempo em termos de sua verificaçâo operacional, isto é: da possibilidade de medi-los através da transmissão de sinais? E ela realmente edificou-se, como uma vulgata o fez crer por muito tempo e como o próprio Reichenbach dá a entender (14), sobre o resultado negativo da experiência de Michelson? Sobre a base de tal interpretação, Reichenbach não encontrou dificuldades em consignar a Einstein uma posição filosófica empirista (15). Fundamenta esta atribuição não sobre a filosofia que Einstein propóe em seus escritos, mas sobre sua suposta caminhada, reconstituída em função de seus objetivos.

Eis aqui, então, o que bastaria para justificar nosso projeto de examinar mais de perto seus escritos: no encaminhamento real que conduziu Einstein à formulação de suas teorias, pelo que seja possível de reconstituir delas elementos significativos, e em suas análises ulteriores que abordam também de maneira mais geral a natureza e os processos do conhecimento. Nestas duas direçóes uma interpretação como a de Reichenbach padece de seus pressupostos, a saber: a eliminaçáo, em suas considerações filosóficas, dos caminhos efetivos da pesquisa e da descoberta, e a idéia que a filosofia deve náo somente ser homogênea à teoria científica mas dela decorrer por via de conseqüência lógica. 
Sem parecer se aperceber que o próprio Einstein propós, entre outras consideraçóes sobre o conhecimento, uma concep̧̧áo completamente diferente da significaçáo filosófica da Relatividade, Reichenbach lhe faz, em nome de um suposto ponto de vista da filosofia, a seguinte censura: "Náo encontramos em seus escritos nem exposiçăo nem argumentaçáo substancial de uma teoria filosófica" (16). Einstein, segundo ele, não tinha sentido a necessidade de se entregar a uma análise aprofundada de sua posição filosófica e dos fundamentos de seu pensamento, juntando-se simplesmente à corrente de físicos que o precedia, aquela dos Kirchhoff, Hertz e Mach, e deixando a outros o cuidado de destacar "a filosofia que implicavam suas equaçóes" (17).

Se se trata exclusivamente de filosofia segundo sistemas nós devemos parar aqui nossa investigação concordando, aliás, de bom grado, com Reichenbach que "a filosofia de Einstein não é tanto um sistema filosófico mas sim uma atitude filosófica". Ainda seria necessário nos interrogarmos sobre o caráter coerente, e mesmo sistemático, de uma tal atitude, e sobre o grau de profundidade ao qual chegou no exame e a posição dos problemas aos quais ela se aplica. Năo admitiremos portanto, sem uma investigaçáo detalhada, que Einstein seria apenas um filosofo por implicafáo, como Reichenbach o propóe. Esta atitude filosoffica reconhecida por ele, teria podido influenciar apenas um momento, restrito em suma, da atividade, e permanecer estranha aos seus primeiros tempos, que Reichenbach remete exclusivamente à física? E se, nestes primeiros tempos, o físico e o filósofo estiveram estreitamente mesclados?

\section{Uma nova separação entre ciência e filosofia. Descoberta e justificação}

Se as tarefas respectivas do cientista e do filósofo são inevitavelmente distintas, pela necessidade das especializaçóes, os argumentos invocados para justificar sua dissociação não são irrespondíveis. Para Reichenbach, é normal que não sejam aqueles que tornaram possível, por seu trabalho em física, a nova filosofia, os que a desenvolvam, ainda que ela esteja implícita em suas construçóes. E é verdade que eles não têm, freqüentemente, esta oportunidade; o trabalho filosoffico tem, também, sua técrica, como o trabalho científico. É verdade, igualmente, que isto náo corresponde realmente a seus objetivos (notadamente se se trata de estabelecer um sistema). Mas já é menos seguro que um e outro requeiram disposiçóes de espírito totalmente diferentes (18): aquele que se aplica às cilncias empiricas preocupando-se, segundo Reichenbach, em adivinhar e em predizer (o que ele opóe - não sem algum arbítrio - ao método da análise crítica), ao contrário do filósofo, cuja atividade 
seria toda analítica e exata, dirigindo-se apenas às relaçóes lógicas, e preocupando-se, aliás, com a justificaçáo, não com a descoberta.

Esta descrição da atividade do físico apoia-se na idéia que a física, enquanto ciencia empirica, propor-se-ia apenas, partindo de certos fatos da experiência, a prever outros fatos verificáveis. Mas é assim que funciona, universalmente, a busca de uma explicaçáo teórica? Aqui vale a pena, também, ver diretamente no processo de raciocínio do físico, tal qual este efetivamente se produz, no contexto da descoberta, táo rápido remetido exclusivamente à psicologia.

Excluir a descoberta, por princípio, da atenção da filosofia náo é excluir de fato todo trabalho de pesquisa científica? E separar de maneira tão decidida o espírito do cientista e do filósofo não é igualmente negar a existência, na atividade do pesquisador, de motivaçóes e procedimentos de ordem racional, possíveis de serem descritos de outra forma que pelo apelo a simples crenças, a exemplo da idéia de harmonia que teria presidido o espírito das pesquisas de Einstein, segundo seu próprio testemunho? (19) Sem minimizar sua importância, uma idéia tão geral e "metafísica " não é suficiente, evidentemente, para dar conta do encaminhamento do pensamento do pesquisador quando ele se aplica a problemas precisos - a năo ser considerando este pensamento como totalmente irracional. Que ela seja subjacente, de forma mais ou menos distante, à motivação e à atividade não elimina em nada as exigências propriamente epistemológicas características deste pensamento e que o próprio Einstein freqüentemente analisou.

Assim, a corrente de idéias que, à primeira vista, dava a impressáo de ser a mais capaz de compreender $o$ aspecto filosófico do pensamento de um cientista como Einstein, revela-se, de fato, limitada e deformante. As razōes disto são a restrição do papel e do método da filosofia àqueles da filosofia analítica, a eliminaçáo da consideraçáo da elaboraçáo teórica (a "descoberta ") do campo da filosofia e, no final das contas, a esterilização do pensamento científico a que chegou uma filosofia que, contudo, se pretendia táo próxima da ciência. Tão próxima, a ponto de propor que "não há acessos separados à verdade para os filósofos" e que "a via do filósofo é indicada pela do cientista" ("tudo o que pode fazer o primeiro, acrescenta, é analisar os resultados da ciência, construir suas significaçóes e discutir sua validade"), e ao ponto de concluir que "a teoria do conhecimento é a análise da ciência" (20). Este cuidado muito cioso da filosofia para com a ciência conduziu a fazer desta última um objeto asséptico, estático, simples esquema formal cobrindo um dado empírico, e a interditar-se de compreender seus movimentos e sua gênese. 


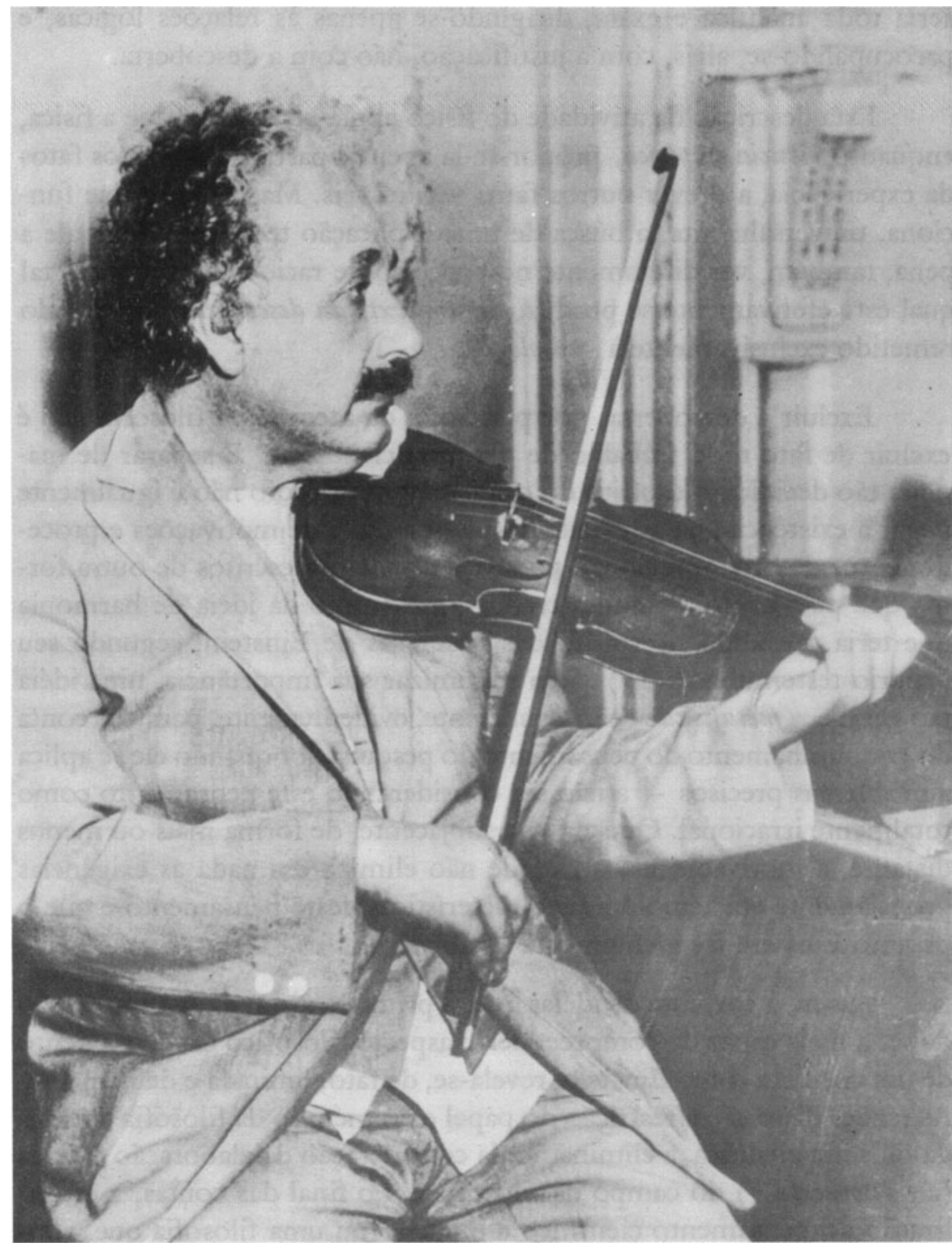

"Não tenho nenhum talento especial. Sou ape nas um curioso apaixonado ", disse Einstein quando perguntaram-lhe se atributa seu talento cientifico ao seu pai e seu talento musical à sua mãe.

Tendo colocado a compreensão da ciência real no leito de Procusto da filosofia assim concebida, Reichenbach pode aliás, apenas estranhar em certos casos, como naquele da Relatividade, se "a análise lógica da teoria coincide com a interpretaçáo original de seu autor", tal como este último a deixa ver no seu trabalho. Reconheceremos, com ele, é certo, que náo é freqüente, em ciências, o caso de uma teoria cujo esquema lógico coincide a este ponto "com o programa que controlou sua 
descoberta" (21). Mas um caso tão significativo deveria suscitar dúvidas sobre a conformidade à razão de interdiçóes metodológicas, que aliás desmente involuntariamente a expressão utilizada. Como um programa controlaria a descoberta se esta última só dependeria da psicologia, e sua motivação somente da metafísica? Tal programa não é intencionalmente racional por definição? Sem parecer se aperceber da contradição, Reichenbach a resolveu, ao fim, invocando a idéia de excefão. Mas esta, de um pensador do qual a "clareza filosófica o distingue (...) de numerosos físicos cujos trabalhos tornaram-se a fonte de uma filosofia diferente da interpretaçáo que eles deram" (22), que soube "ser o primeiro a ver todas estas relaçóes [os efeitos filosóficos de sua teoria] ainda que ele não as tenha sempre formulado de maneira explícita", cujo trabalho em física "contém mais filosofia implícita que muitos dos sistemas filosóficos" (23) e que, sob este aspecto, é o sucessor de Newton.

Einstein

andando de

icicleta na casa

de um amigo proximindades de Los Angeles

(EUA), em fevereiro de 1933.

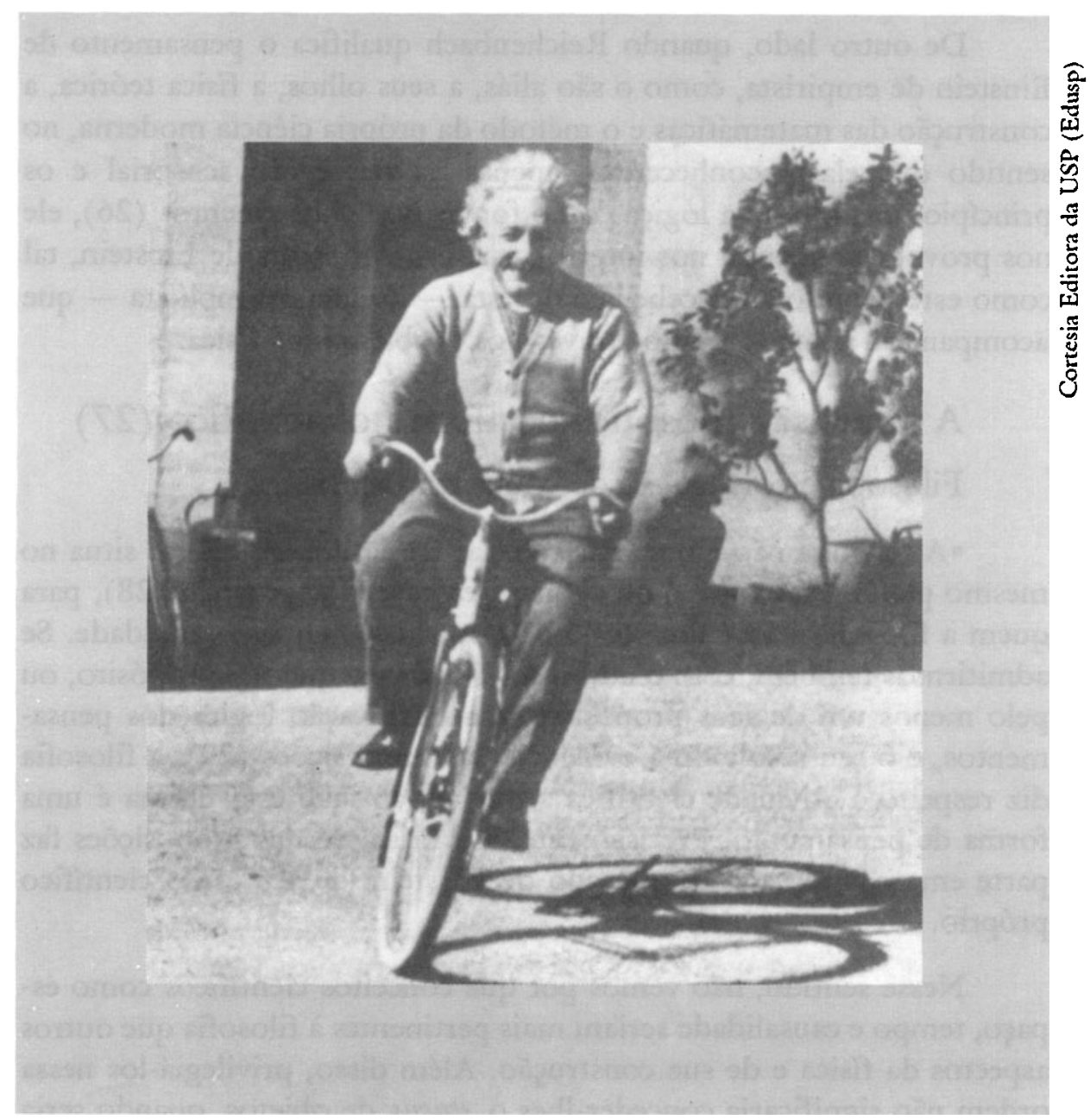


De fato, os raciocínios que levaram Einstein à teoria da Relatividade mostram bem o quanto a anólise lógica pertence, ela mesma, ao trabalho original da teoria. Reichenbach sublinha este aspecto a propósito da análise da simultaneidade, e deste estado de coisas mais geral segundo o qual as definiçóes da teoria da Relatividade são todas do tipo coordenativas (24). Mas isto apenas designa, nele, uma concepçáo do espaço e do tempo que tem por efeito notável (e filosoficamente decisivo) ocasionar a "dissoluçáo do sintético a priori (25). Podemos, ao contrário, nos perguntar se a teoria da Relatividade é somente uma doutrina do espaço-tempo, e se sua elaboraçáo somente implicou a reflexáo sobre estes conceitos como momento filosófico. E se a abordagem de Einstein não é melhor caracterizada por uma posiçáo própria (e de natureza filosófica) com referência aos princípios e conceitos, a seus papéis em uma teoria, à relação desta última com os fenômenos dados na experiência (ver-se-ia que aí o papel da análise lógica não é menor). Estudá-la será tentar entrar nas razóes que levam à descoberta.

De outro lado, quando Reichenbach qualifica o pensamento de Einstein de empirista, como o são aliás, a seus olhos, a física teórica, a construçáo das matemáticas e o método da própria ciência moderna, no sentido que elas reconheceriam apenas "a percepçáo sensorial e os princípios analíticos da lógica como fontes do conhecimento" (26), ele nos provoca também a nos interrogar sobre a filosofia de Einstein, tal como este próprio a concebe, além desta - ao menos implícita - que acompanhou o seu caminho através dos problemas de física.

\section{A dimensão filosófica do trabalho científico (27)}

\section{Filosofia e construção de conceitos científicos}

"A filosofia não é uma das ciências da natureza", não se situa no mesmo plano; está "acima ou abaixo", escreve Wittgenstein (28), para quem a filosofia não é um corpo de doutrinas, mas uma atividade. Se admitirmos também, com o autor do Tractatus, que seu propósito, ou pelo menos um de seus propósitos, é a clarificaçăo lógica dos pensamentos, e o seu resultado a evidência das proposiçóes (29), a filosofia diz respeito à atividade científica à medida em que esta última é uma forma de pensamento. Precisamente, a clarificação das proposiçóes faz parte em grau elevado do método de Einstein, de seu estilo científico próprio.

Nesse sentido, não vemos por que conceitos científicos como espaço, tempo e causalidade seriam mais pertinentes à filosofia que outros aspectos da física e de sua construçáo. Além disso, privilegiá-los nessa ordem năo significaria conceder-lhes o status de objetos, quando seria 
preciso considerar, ao contrário, com Gilles $\mathrm{G}$. Granger, ser a filosofia uma "disciplina sem objeto" (30), que não se preocupa tanto com a descrição, mas em destacar ou "interpretar as significaçóes", substituindo os fenômenos, seus conceitos e esquemas representativos, "na perspectiva de uma totalidade", por oposiçăo à ciência no sentido estrito, que "constrói estruturas de objetos" e, para fazê-lo, fragmenta (31) e simplifica?

Podemos nos perguntar, entretanto, se a distinção é táo nítida em todos os casos e se a constituição de objetos de ciência não está, quase sempre, acompanhada de uma elucidação que tem por objeto, precisamente, as significaçóes. Náo é somente em uma fase ultrapassada da história do pensamento que filosofia e ciência se confundem até determinado ponto, em um terreno comum (32). O fato de uma implicar a outra tem a ver tanto com o momento de surgimento de uma concepçáo teórica nova (a descoberta), como com o de reorganizaçáo do esquema teórico, no qual nos esforçamos para exprimir a significaçáo das proposiçôes.

É aqui que a relação entre ciência, como descrição, e filosofia, como expressão e ordenamento das significaçōes, aparece em toda a sua complexidade, já que a ciência (por exemplo, uma dada teoria) traz em si mesma a necessidade de sua própria interpretaçáo. Todos os debates sobre a física contemporânea versam sobre a natureza desta interpretação e da instância à qual as significaçóes das proposiçóes devem estar relacionadas. A contribuiçáo do próprio Einstein nesses debates destacase por sua preocupação em distinguir o mais nitidamente possível o que, na interpretação, provém estritamente da física (quer dizer, da ciência como descrição e interpretação) e o que depende de uma posição filosófica (mais geral e totalizante). É, em particular, o caso de suas consideraçóes sobre a mecânica quântica. Esclarecendo a significaçáo das proposições, no caso, as da teoria física - segundo a missão conferida por Wittgenstein à atividade filosófica -, Einstein distingue ciência e filosofia ao invés de mesclá-las indevidamente. Com esse procedimento, ele demonstra, ainda melhor, a verdadeira natureza de sua implicação comum.

A física, como toda ciência particular, toma emprestado da filosofia elementos de significaçáo. Este é, principalmente, o caso das categorias gerais como as de ordem, lei, causalidade e determinismo, mas também as de teoria e princípio, sem as quais esta ciência não poderia definir seus objetos e procedimentos, nem mesmo ser pensada (33). Os conceitos que são aparentemente os mais ligados à experiência são entidades abstratas que possuem uma funçáo num conjunto, no qual re- 
cebem sua definição operatória e adquirem sentido (físico, no caso dessa ciência). São, por isso, devedores das categorias gerais mencionadas e a reflexáo sobre eles, fosse esta precisa e técrica, sobre sua ligaçáo com a experiência e sua significação teórica, possui uma parte ligada à atividade filosófica ao mesmo tempo que ela faz parte do trabalho científico propriamente dito.

Vejamos isto através de um exemplo. Quando em sua obra de 1917, A teoria da Relatividade restrita e geral (34), Einstein escreve que "o conceito existe para o físico somente quando temos a possibilidade de encontrar no caso concreto, se o conceito se aplica ou náo", ele deixa intocada a questáo da natureza e da origem do conceito, e dá apenas uma indicação relativamente geral sobre sua significação para a física: a aplicaf̧ño no caso concreto, isto é mais amplo que a consideração exclusiva da experiência (referência exclusiva do positivista) e remete à situafão física, objeto de estudo do físico. Mas, apesar de sua imprecisáo, a estipulação permite ver o que constitui o caráter fisico de um conceito, submetido a especificaçōes precisas, ditadas pela natureza e propriedades do sistema físico que consideramos.

Esta observaçáo de Einstein - feita a propósito do espaço e do tempo - forneceu a Ernst Cassirer a ocasiáo de aprofundar a questão da significação dos conceitos. Para Cassirer, "os papéis respectivos da física e da filosofia situam-se sobre as duas vertentes de uma mesma exigência de unidade do abstrato e do concreto, neste sentido que a teoria [entendamos: a física] vai da experiência à idéia, enquanto que a outra [a filosofia] vai da idéia à experiêncian. Mesmo quando o físico limita-se a considerar (por exemplo, para os conceitos evocados) a coincidência de acontecimentos no espaço e no tempo, ele mantém, segundo Cassirer, na definição destes acontecimentos, uma dimensão lógicomatemática que é de todo modo a condiçáo de possibilidade de seu pensamento; os conceitos que comparecem (número, espaço-tempo, funçáo) são conhecidos do físico apenas por sua combinaçáo recíproca. Mas é papel do filósofo do conhecimento analisar os elementos desta combinação; ele não admite que a significação do conceito seja identificável à sua aplicaçáo concreta, ao contrário, ele sublinha que a significação deve ser estabelecida para que uma aplicação possa ser feita (35).

"O pensamento do espaço e do tempo em suas significaçóes como formas de colocaçáo em relaçáo de ordem", escreve Cassirer, "não é criado inicialmente pela medida; ele é somente mais estreitamente caracterizado por esta última, que lhe dá um conteúdo definido. Nós devemos ter apreendido o conceito de evento como alguma coisa de espaço-temporal, nós devemos ter compreendido a significaçáo que nis- 
to se expressa, antes de poder nos interrogar sobre a coincidência dos eventos e de procurar estabelecê-la por métodos particulares de medidas" (36). Insistindo a propósito da teoria da Relatividade, sobre o fato que a significaçáo dos conceitos precede à experiência, e que esta significaçáo reside em sua imbricaçáo lógico-matemática, Cassirer quer sublinhar uma ligação estreita entre a física e a filosofia. Reivindica para a filosofia esta clarificação (restringindo o papel da física à relação que faz passar da experiência ao conceito, ele junta-se à concepçáo positivista), e vê então esta ligação como uma dependência da física com relaçáo à filosofia, pois é a esta que cabe o papel de revelar a significaçáo que precede a experiência. Mas, se abstrairmos uma divisão de trabalho tão acentuada quanto a vista por Cassirer, e se, por outro lado, nos interrogarmos o que foi mesmo a atividade de Einstein, nos apercebemos que o papel do físico comporta também, pelo menos em parte, esta tarefa que Cassirer atribui exclusivamente à filosofia. De fato Einstein estava longe de simplesmente remeter o conceito do físico à medida.

Ao final das contas, os papéis do físico e do filósofo não são tão demarcados e, desembaraçando-a de suas concessóes ao positivismo suposto na atividade do pesquisador, podemos exprimir de outro modo a idéia levantada por Cassirer: a tarefa do físico é, inseparavelmente, enunciar a significação dos conceitos, estabelecendo sua identificaçăo lógico-matemática, e ligá-los à experiência.

Poderíamos dizer que os conceitos em questáo náo sáo realmente de natureza filosófica e que sua significação é dada no próprio sistema teórico, isto é, pela física. Mas, de maneira geral, as ciências, mesmo consideradas em seu aspecto mais formal, puramente lógico-teórico, não podem ser concebidas como fechadas nelas mesmas (veja a importância, desse ponto de vista, do teorema da incompletude de Godel), e a significação de seus conceitos e de suas proposiçóes ultrapassa a ordem lógico-teórica que Cassirer parece lhe atribuir: ela requer os metaconceitos da filosofia (37). De modo que, a afirmação por Cassirer de uma ligação entre ciência e filosofia é ainda válida, mesmo que deslocada devido à atribuiçăo diferente do papel da definiçáo teórica em relaçáo ao trabalho do físico. Por outro lado, a questáo da significaçáo dos conceitos e das proposiçóes de uma teoria é de natureza complexa: exige clarificaçáo e distinção entre o que pertence, respectivamente, à física (mais geralmente, à ciência) e à filosofia. Ora, tal clarificaçăo e distinção supōem uma atenção aos metaconceitos e evidenciam a sensibilidade filosófica do físico que os utiliza, isto $e$, destacam o lado filosófico desse trabalho teórico.

O enunciado das significaçóes - inclusive seu ordenamento se- 
gundo uma perspectiva que as relaciona à unidade do conhecimento faz parte da atividade do físico, que recebe daí uma dimensáo diretamente filosófica. $O$ que, é preciso frisar, não substitui o trabalho posterior do filósofo no sentido de desvendar os significados num desenho mais amplo. Mas a clivagem náo é tão nítida e vemos que a física, por ter algo de fundamental, é também filosofia.

Além dessa atividade com os conceitos, existem outros aspectos filosóficos consubstanciais à ciência - nem exteriores a ela, nem posteriores - que participam igualmente do pensamento e do trabalho científicos, que se encarnam neles e que constituem, por assim dizer, o estofo do questionamento científico cotidiano (38). Tais sáo, principalmente, as questóes referentes à natureza $\mathrm{e}$ a validade do conhecimento científico, à estrutura formal ou lógica das teorias, à determinaçăo de sua relaçáo com a experiência. Tais são, da mesma forma, certas disposições que Einstein atribui ao pesquisador, cujo conjunto pareceria eclético aos olhos do filbosofo sistemático, mas que não são menos filosóficas pelo fato de cada uma delas não constituir um sistema: o projeto de representar uma realidade independente, a parte de convençáo nesta construçáo, sua justificação pelo elo que possui com as experiências dos sentidos, a escolha do critério de simplicidade lógica... (39) A filosofia do conhecimento pode, certamente, considerar essas questóes abstraindo a prática particular de cada pesquisador relativamente a um problema dado, para alcançar - ou, pelo menos, para problematizar - as características gerais dessa forma de pensamento que é a ciência. Mas, de outro lado, essas concepçóes, sejam conscientes e críticas, ou não formuladas ou simplesmente herdadas, fazem parte do material a partir do qual trabalha 0 pesquisador: incorporadas às suas ferramentas intelectuais, elas influem sobre sua investigaçáo mesma, representando, segundo o caso, um papel heurístico ou de bloqueio... Constituem elementos de seu programa (40), e é quase sempre com referência a elas que um cientista julga o êxito, ou nảo, do que conseguiu (ele mesmo ou a ciência à qual está ligado).

Como tal, a filosofia se encontra $n a$ ciência, no seu movimento e textura e năo somente na avaliaçăo posterior de seus resultados. Compreendemos, então, como a atividade filosófica - mesmo considerada como simples atitude, predisposiçáo ou sensibilidade particular a estes aspectos - pode estar presente no seio do trabalho científico. Esta atividade filosófica pode ser bastante explícita e adquirir importância decisiva na investigação científica, através da reflexão crítica do cientista sobre questóes epistemológicas de natureza conceitual ou metodológica (41). O filósofo e o cientista, neste caso, constituem um só, náo pela ocasião, mas pela natureza do conhecimento científico. 
Se é preciso distinguir ciência e filosofia - distinçáo necessária mesmo após o que foi dito -, náo é porque elas têm muito a ver uma com a outra e porque possuem implicaçóes mútuas? Quando Alexandre Koyré declara que "está fora de dúvida que foi uma meditaçáo filosófica que inspirou a obra de Einstein" - e que, portanto, "poderíamos dizer que, como Newton, ele foi filósofo tanto quanto físico" - , é a esta ligaçáo constitutiva que ele faz referência. Ele remete tal ligação à afirmação de um "princípio metafísico" (42), que fez com que Einstein escolhesse alguns absolutos e rejeitasse outros. Absolutos esses (invariância, certos tipos de leis), fundados na "natureza que é a medida das coisas tal como elas sãon, e náo mais em Deus (Newton) ou no sujeito cognoscente (Kant). Podemos, certamente, discutir, no detalhe, a argumentação de Koyré e encontrar alguma ambigüidade em sua afirmação segundo a qual "hoje como no tempo de Descartes um livro de física começa por um tratado filosófico" (43). Ela se presta a mal-entendidos se pensarmos que o trabalho científico começa pelo enunciado de uma posição ou de um problema filosófico. É o próprio conteúdo das questóes científicas, consideradas em suas especificidades e nas tecnicidades de suas formulações, que revela ao mesmo tempo sua dimensáo e seu alcance filosófico.

De sorte que pensamento físico e pensamento filosófico mantêm estreita relaçáo, da atividade criadora aos debates sobre interpretaçáo. Mas as considerações gerais sobre a natureza exata desta relaçáo são ainda imprecisas e somente o exame de situaçóes efetivas, e dos pensamentos dos cientistas eles próprios, em sua diversidade, podem nos instruir.

A idéia de filosofia permanece ligada à modalidade de ser, ao mesmo tempo, uma atitude e uma atividade, com o que isto supóe de investigação pessoal e de "busca" ". Era desse modo, como uma investigaçáo que o engajava inteiramente, sem garantia alguma de chegar a um resultado visível, que Einstein concebia sua própria atividade científica. Ele emitiu, a este propósito, consideraçóes sobre a oposiçáo entre esta busca desinteressada e o ofício necessário para viver, invocando Spinoza, que vivia do ofício de artesăo polidor de lentes (44). Einstein é, evidentemente, filósofo neste sentido geral, além das especializaçóes. Mas é também na acepçáo mais precisa do termo filosofia, como questionamento racional desenvolvendo conceitos, buscando compreendêlos e ordenando suas significaçóes, que nós consideraremos o pensamento de Einstein enquanto pensamento filosófico: de um lado, pelo objeto (de ciência) ao qual ele aplica seu pensamento e pela sua abordagem particular deste objeto; de outro lado, por sua reflexáo episte- 
mológica e filosófica a respeito da atividade do conhecimento científico. Este projeto apela a duas hipóteses de trabalho ligadas às consideraçóes que precedem.

\section{Racionalidade da descoberta}

Trata-se de saber, antes de mais nada, se a filosofia como pensamento crítico deve dar atençáo apenas às proposiçóes finais de uma ciência (finais no sentido provisório, quer dizer pelo que sua formulação lhe tenha deixado momentaneamente estabilizada), e de questionar se a legitimidade da filosofia não se adequaria igualmente bem ao exame desses momentos eminentemente transitórios da formulaçáo de problemas científicos, considerados em seus momentos constitutivos, transitórios e singulares (transitórios porque estes problemas e suas soluçôes ver-se-âo reformulados, e singulares porque esta elaboraçáo é fruto de reflexōes individuais).

Admitiremos que sim, contra a opiniáo daqueles que, com Reichenbach, remetem esta consideração a uma psicologia da descoberta, excluindo por princípio um tal objeto da aproximaçáo crítica da filosofia (45). Renunciar ao exame dos problemas da descoberta seria, para a filosofia, abandonar um imenso campo de problemas que dizem respeito ao conhecimento racional, ocultando a fase de elaboração de uma ciência entre seus primeiros tateios e sua formalizaçáo. Além disso, esta fase recobre, algumas vezes, um amplo espectro temporal (como, por exemplo, no caso da teoria quântica). Na verdade, poucos trabalhos filosóficos tratam realmente da descoberta: sociólogos e historiadores (relativistas) das ciências contemporâneas têm todas as condiçóes para apropriar-se disso, no terreno que lhes foi concedido, longe da racionalidade (46).

Karl Popper, em Lógica da pesquisa, ou da descoberta cientifica, considera somente os desenvolvimentos da ciência e não a descoberta em si mesma (47). Ele descarta esta última da "análise lógica " da ciência, como fazem os positivistas e empiristas lógicos, e reméte-a, do mesmo modo, à "psicologia emptrica ". Popper rejeita também todo esforço de reconstruir o processo de "inspiraf̧áo ", invocando o que ele possui de "elemento irracional " (48). Esta rejeiçăo liga-se à sua epistemologia: não existe lógica da descoberta, já que não existe induçáo, ou seja, inferência lógica de uma proposição geral a partir de asserçôes singulares.

Mas se por esta razão é possível aceitar que não existe uma " lógida descoberta propriamente dita, o problema de uma racionali- 
dade da descoberta, logo da pertinência desta última para a filosofia das ciências, permanece de pé. O termo " lógica ", a se fixar nele, implica uma visão estreita, não deixando outra escolha senāo entre um esquema obrigatório fixo, rígido, de mão única e um fator, ou elemento irracional, sobre o qual nada podemos dizer (49). Colocar, ao invés da lógica, a questáo da racionalidade - da qual a lógica é apenas o esqueleto da descoberta, permite levar em consideraçăo um objeto de determinaçóes mais complexas, admitir o papel da intuiçăo, ao menos em uma certa acepçáo do termo e, mesmo deixando sua parte aos elementos contingentes ou irracionais, fazer jus ao caráter fundamentalmente racional do trabalho de criaçáo científica. De resto, este caráter se revela imediatamente nisto que a fase mesma da elaboraçáo comporta a cada passo, da parte do pesquisador, reorganizaçōes racionais (senắo " reconstrufóes " ) como ordenaçóes dos elementos que estuda, para os compreender. A tentativa de Lakatos (50), de dar conta do desenvolvimento da ciência e de seu progresso propondo sua "metodologia dos programas cientificos de pesquisa ", mantém uma "lógica da descoberta " (ao menos para os períodos de "crise ") que lembra, em certo sentido, tais reorganizaçōes comandadas por um programa. Mas a "reconstrugáo " de Lakatos, injetando racionalidade em seu objeto de estudo ao invés de aí procurá-la, toma liberdades com a exatidáo histórica e deixa largamente aberta a questáo da racionalidade do processo efetivo de descoberta e do trabalho científico (51).

De fato, enquanto os filósofos da ciência mandavam interdiçóes ou debatiam em torno do princípio (52), a história da ciência, assim como a observaçáo direta dos trabalhos científicos contemporâneos, revelaram a racionalidade dentro do campo dos problemas e do trabalho de elaboração, sem que fosse necessário esperar o momento das reorganizações ou das reconistrufóes racionais.

Quando examinamos a fase de elaboraçáo, não encontramos um número menor de questōes pertinentes do ponto de vista da epistemologia e da filosofia do conhecimento, do que quando nos interrogamos sobre proposiçóes fixadas, com a vantagem suplementar de poder, eventualmente, apreender algo da dinâmica dos problemas responsável pelo movimento da ciência e da realidade do pensamento científico em trabalho. As relaçóes entre os conceitos não estabilizados não são, por isso, menos estruturadas racionalmente, seja do ponto de vista da lógica de suas conexóes, ou por sua relaçáo com os dados de experiência, mesmo se a lógica destas conexóes é menos transparente. Esta estruturaçáo provisória, ainda que diferente da forma final, se esclarece na análise em elementos de significação, que permitem melhor discernir o caráter racional do pensamento científico, assim como certos traços da evoluçáo 
dos conceitos e das teorias. Os debates sobre interpretaçáo, que acompanham freqüentemente a aparição de uma nova concepção, ou teoria, sem esperar a formulação final, são, sob este aspecto, reveladores (53).

Concluímos, então, que a racionalidade jamais deixa de impregnar a atividade intelectual do pesquisador mesmo se, em seu movimento efetivo, esta seja tributária de outros fatores. Não se trata de explicar ou de dar conta da totalidade do processo de descoberta, mas de esclarecer sua racionalidade sem, por isso, reconstitut-la racionalmente.

Por outro lado, o estudo das condiçōes de possibilidade de uma concepçáo teórica, ou de uma ciência, não pode fazer a economia da consideraçáo das circunstâncias que acompanhassem seu estabelecimento. Isto é mais verdadeiro à medida em que a filosofia do conhecimento, tal como é requisitada em nossos dias, e diferentemente da filosofia transcendental, não se propõe a fundar uma ciência constituída e de proposiçóes imutáveis, mas considerando a ciência da maneira como está dada, quer dizer, como conteúdo (provisório) e como processo, sabendo que ela está sempre em gênese, interroga-se sobre a sua significaçáo e seu o conteúdo de verdade. A legitimidade mesma da filosofia do conhecimento está em jogo na possibilidade, por ela, de poder se interrogar sobre a gênese da ciência e que esta seja, em certo grau, racional. Tal é, pois, a primeira hipótese subjacente ao nosso estudo.

A segunda é que a filosofia não se encontra somente pelo olhar que lança do exterior sobre as ciências, considerando estas seja em suas proposiçóes estáticas ou no movimento que estabelece e transforma essas proposiçóes. Ela existe também - se náo sempre e de modo sistemático, pelo menos em numerosos e significativos casos - como atitude e como atividade, no movimento do conhecimento científico e, particularmente, no momento em que aparece um elemento de nopidade, que vai se mostrar decisivo (54). E o que, na seqüência, nos esforçaremos para esclarecer.

Semelhante hipótese está relacionada à precedente: se existe uma racionalidade da descoberta e se a clarificação dos problemas submetidos a exame, a atualizaçáo e $o$ ordenamento das significaçóes dela participam, não é possível dizer que o trabalho correspondente a todo esse processo é também de natureza filosófica? Neste caso, a filosofia compreenderia também o movimento que estabelece as proposiçóes fundamentais da ciência. Observemos, como um dos efeitos desta hipótese, que é possível entender como em alguns casos, por raros que sejam, a "lógica " do raciocínio da "descoberta " corresponde à da "justifica- 
fẫo ", como notava Reichenbach a respeito da Relatividade, estranhando o fato.

Problemas de física, objetos de reflexão filosófica

Uma das teses deste livro é precisamente que a atividade de Einstein (como atitude e como pensamento) é de natureza profundamente filosófica. Isto não quer dizer, evidentemente, que ele teria sido menos físico que filósofo, como se tomássemos ao pé da letra esta confissáioa um amigo - apesar de reveladora quanto à natureza fundamental de suas preocupaçōes: "Eu não sou verdadeiramente um físico, mas sim um filósofo, e mesmo um metafísico." Não entendemos tampouco por isto que ele seria um filósofo do espaço-tempo, e depois da unidade das coisas, e que o resto da física não o interessaria verdadeiramente: seus críticos, os físicos quânticos, eles mesmos, náo pensavam assim.

Mas se devíamos dar uma qualificação lapidar de sua atitude intelectual, do tipo de questóes que ele se colocava, e de sua maneira de resolvê-las, o termo que se imporia mais imediatamente seria o de filosofia. No momento mesmo em que ele se interessava pelos problemas de física, e sendo físico plenamente, Einstein pensava também como filósofo : o espaço-tempo não sendo aqui senão um dos objetos de sua atenção, entre outros cujas implicações são totalmente filosóficas, e estes objetos, submetidos ao pensamento do físico, sendo em si mesmos, e náo somente por suas conseqüuências, objetos de uma reflexão da qual veremos que bem pode ser dita filosófica.

Esta qualificação não é subsidiária ou simples questão de gosto. Para o nosso projeto, que é de compreender o pensamento de Einstein nos diferentes domínios aos quais ele se aplicou, e notadamente a relação entre seu pensamento físico, em seu trabalho de físico, e suas concepçóes mais gerais, isto é sua filosofia do conbecimento, ela é - pelo que ela seja justificada - de uma importância considerável. O alcance da questáo colocada estende-se além do caso particular de Einstein, atingindo a natureza mesma da física e, mais geralmente, da ciência. Ela indaga, a partir da obra dos pesquisadores, sobre a natureza profunda do conhecimento científico. Qual é a forma de pensamento da física? Que gênero de trabalho é o do físico? O que é, exatamente, um objeto de ciência? Que espécie de questóes o pesquisador se coloca sobre tal objeto? Qual é, em profundidade, sua natureza? Não é casual que este mesmo objeto suscite, além de sua elucidação por uma ciência, o interesse da filosofia que se interroga sobre o conbecimento deste objeto de ciência. A filosofia se interessaria pelo objeto, da maneira como faz, se 
este não estivesse impregnado por suas questóes desde o seu nascimento e constituiçáo?

A filosofia que a atividade cientifica implica apresenta-se, entáo, no próprio movimento desta última, e compreende tanto o período da descoberta quanto da interpretaçáo de seus problemas, resultados e proposiçóes, nos diferentes níveis nos quais podemos examinar esta interpretaçăo.

Talvez seja a consciência da dupla implicaçáo de seu objeto de estudo que dá ao pensamento dos cientistas-filbsofos seu interesse particular. Năo é uma coincidência que os torna pesquisadores em sua ciência e filósofos ao mesmo tempo; talvez não tenhamos prestado suficiente atenção à relação entre o seu trabalho científico e suas contribuiçóes filosóficas (55). Estudando diversos casos, vemos que a dependência dos dois não é unívoca: não é uma filosofia inicial que determina o trabalho científico, nem este último que engendra, pela via da conseqüência, as concepçóes filosóficas. Deixando de lado as concepçóes herdadas $(e, \mathrm{em}$ particular, as pressuposiçóes de natureza filosófica na formaçáo científica), parece, mais profundamente, que a atividade científica e a interrogaçăo filosófica que a acompanha nesses pensadores manifestam-se juntas, sem uma defasagem importante entre elas, como se surgissem de uma só fonte de problemas, cuja natureza seria inicialmente indistinta, filosófica e científica de uma só vez, ainda que a atençăo se encontre dirigida a um objeto de ciência circunscrito e preciso. Este objeto excede a simples positividade de sua própria descrição bem como do resultado do qual ele é a ocasiáo.

Is̀to não quer dizer que, posteriormente, não exista distinção a ser feita entre o caráter científico e o filosófico; compete à epistemologia assinalar o que, no estudo de um problema ou conceito, pertence estritamente à disciplina científica considerada e o que aparece como sua dimensão, ou suas implicaçóes filośfficas. A clarificaçáo é necessária se queremos assegurar a autonomia da teoria científica em seu campo próprio. Sem autonomia, a ciência estaria $\mathrm{em}$ um estado de dependência arbitrária com relaçăo à filosofia. Mas em um contexto em que se desenha uma situaçáo inédita para os elementos teóricos - e principalmente quando aparecem novos, irredutíveis aos antigos -, a distinção náo é sempre possfivel imediatamente, e só o é após uma decantaçáo, que corresponde à assimilaçáo da novidade ou da diferença. Apesar da diferença de natureza, ciência e filosofia acompanham-se de perto, a ponto de parecerem produzidas uma com a outra, se não uma pela outra, indissociavelmente: um mesmo movimento as envolve em seu surgimen- 
to. Este parece ser o caso, ao menos nos momentos profundamente criadores das ciências particulares.

É preciso deixar claro que os problemas científicos não săo homogêneos e uns sáo mais predispostos que outros à atençáo filosófica. Notamos também semelhante diversidade entre os cientistas, sobretudo na época das especializaçóes, na qual a tecnicidade pode mascarar uma dimensáo mais ampla. Mas, na verdade, nem especializafáo nem tecnicidade se opóem ao alcance geral (no sentido de significaçáo em uma totalidade) ou filosofico, como os problemas tratados por Einstein fazem ver. Se existe uma oposição entre uma atividade científica correspondente a uma pratica filosoffica e uma outra que lhe corresponderia menos, ou lhe seria estranha, năo é nesses termos que a exprimiremos.

Não prejulgaremos a natureza real de uma tal oposição, ou do que faz a diferença entre as diversas atitudes, ou estilos científicos. Sem identificar ciência e filosofia, será suficiente investigar o que as aproxima, no caso de um pensamento criador particular, tentando ver como um problema considerado científico revela algo que tem a natureza de um problema filosófico e vice-versa. E, talvez, contribuir para esclarecer com isso a natureza da ciência como pensamento.

Uma origem comum de qualificação no pensamento criador

$\hat{E}$ a busca desta origem comum de qualificação que nos interessa aqui, em primeiro plano: origem comum no objeto de investigação, assim como na motivaçáo e no estilo de procedimento do pesquisador.

O estilo é o que constitui a marca própria da individualidade de um pesquisador na sua abordagem do problema científico. Esta abordagem tende à objetividade, mas seu trabalho não é apenas de natureza lógica e dedutiva. $O$ objeto de investigação, mesmo quando suficientemente circunscrito - por exemplo, no período 1900-1905 a necessidade, para a teoria física, de uma formulação satisfatória da eletrodinâmica -, não se deixa descrever de forma unívoca: a diversidade de suas possíveis determinaçóes define um campo de raionalidade no qual o trabalho científico individual se efetua (56).

O exame comparativo dos trabalhos de diferentes pesquisadores sobre um mesmo problema, ou objeto, em uma mesma época, permite caracterizar as diferenças de abordagens entre os pesquisadores, a particularidade de cada um de seus estilos. Semelhante estudo pode evidenciar a racionalidade da descoberta : ele indica como escolhas distintas foram feitas na diversidade das que eram possíveis entre os elementos suscetíveis de conduzir à determinaçáo do objeto, e que devem pouco ao 
acaso e ao irracional. Tais escolhas não existem num espaço ideal abstrato, ao contrário, sáo postas a pensamentos individuais, e a cada um deles, sob diferentes modalidades: cada um desses pensamentos lê diferentemente o problema estudado. O procedimento de cada pesquisador é deliberadamente racional, orientado para um objeto que lhe é exterior $e$, ao mesmo tempo, marcado por características que definem sua individualidade: $o$ estilo corresponde, precisamente, a esta integraçáo do individual em um trabalho do pensamento que visa a objetividade.

Esta noçăo, tal como é desenvolvida por G. Granger em sua Pbilosophie du style (57), permite visualizar a dialética do individual e do objetivo no processo de trabalho intelectual, preservando assim a racionalidade, ao invés de dissolvê-la como faz a concepção objetivante (58), que prende-se a uma dualidade estática e fechada entre o lógico e o irracional. Os níveis de individualização da prática científica, nos quais os efeitos de estilo aparecem, ligam-se, de um lado, à multiplicidade de estruturas (ou representaçóes teóricas) possíveis, de outro, à caracterologia das abordagens científicas (diferenças dos perfis intelectuais, escolhas metateóricas etc.); enfim, relacionam-se à contingência das situaçöes (59).

Podemos considerar que o estilo do pesquisador é a carne mesma da racionalização (60), que finaliza por cristalizar uma estrutura, uma teoria constituída, capaz de redesenhar o objeto inicialmente escolhido. O estilo tem a ver, de maneira evidente, com as significaçóes (61), principalmente quanto à interpretação das proposiçōes teóricas. No caso das ciências de conteúdo empírico, como a física, as estruturas ou representaçóes teóricas possíveis diante de um problema dado são múltiplas, e é particularmente interessante relacionar o estilo próprio do pesquisador, e o tipo de teoria por ele obtido, com o significado correspondente à teoria em questáo. Se a análise do estilo, que diz respeito às significaçóes, pertence à filosofia, não é menos verdadeiro que o estilo, com as significaçōes que comporta, compreende a filosofia prática do pesquisador. Reencontramos com ele a impregnaçáo filosófica conscientemente marcada, em maior ou menor grau, da atividade cientifica.

O caráter filosofico da pesquisa de Einstein, assemelhada a uma verdadeira busca, é legível desde seus primeiros trabalhos e é responsável, $\mathrm{em}$ boa parte, por sua originalidade: podemos nos perguntar sobre o seu efeito na natureza dos resultados que ele obtém. A relaçáo entre a perspectiva adotada, ou entrevista (que determina uma maneira própria de colocar o problema) e o resultado (levado em seguida a uma dimensão universal) não implica, para além da contingência do percurso 
individual, que a filosofia seja suscitada pela própria natureza do objeto (científico) da investigação! Uma perspicácia particular na consideraçáo dos objetos da ciência não seria o que caracteriza um estilo, que nós poderíamos qualificar neste sentido de prática filosofica? Tal perspicácia não lhe daria uma espécie de faro (que Einstein chamava de sua intuifño ou instinto) que lhe permite destacar objetos de efeitos desencadeadores (para o pensamento) consideráveis (os da Relatividade restrita e geral, da cosmologia e, em física quântica, a introduçáo da análise estatística, ou o diagnóstico de certos traços específicos como a dualidade onda-partícula) ou, ao menos, pressentir com acuidade o que ainda falta para ir em frente, com maior profundidade (notadamente nesta mesma física quântica)? Sobre isto, somente a análise dos trabalhos evocados poderá nos instruir: daí a necessidade de ir, desde o início, aos trabalhos científicos de Einstein, descobridores de objetos de pensamento e fundadores de ciência, ou críticos de soluçōes propostas.

Em verdade, o caso de Einstein, mesmo sendo particular, revela um aspecto universal da atividade e do pensamento científico, por pouco que eles sejam de natureza fundamental. Que este aspecto náo se apresente sempre sob aparências tâo claras não diminui sua importância essencial nos outros casos, se queremos compreender o que é a natureza da ciência

O pensamento filosófico de Einstein: relatividade, geometriá, física dos quanta, epistemologia

O pensamento de Einstein é um universo no qual ainda náo demos a volta. Os numerosos escritos do cientista, dos quais uma grande parte permanece inédita (62), suscitaráo durante muito tempo os esforços dos pesquisadores, cientistas, filósofos, historiadores das ciências e das idéias. Nosso propósito, neste livro, é contribuir para um melhor conhecimento deste pensamento e da filosofia que o anima, segundo a perspectiva esboçada pelas observaçóes que precedem: um conhecimento em profundidade, sem pretensão à exaustividade, nem dos temas, nem da obra estudada. Pelo menos, nos esforçaremos para ser táo completos quanto possível sobre os aspectos que escolhemos para examinar. Nós nos deteremos na filosofia de Einstein tal qual ela aparece através de suas contribuiçóes científicas e seu pensamento da física e da ciência, deixando essencialmente de lado as questóes que dizem respeito a outros domínios sobre os quais ele tanto se preocupou, como a ética, a política, a metafísica (63).

Nossa investigação está orientada em torno de três temas. O pri- 
meiro é o do trabalho científico, das contribuições em física e da descoberta, nos quais se manifesta o estilo do pesquisador e sua impregnação filosófica. O segundo dirige-se ao pensamento dos conceitos e das proposiçóes da física, que diz respeito às significaçóes, isto é, dirige-se a epistemologia desta ciência segundo Einstein. Estes dois aspectos temáticos estão ligados, em razáo de sua imbricaçáo, em seu trabalho de pesquisa em física, de elaboração teórica e de crítica epistemológica, mais também na sua epistemologia propriamente dita, que se nutre de sua experiência pessoal e é inseparável de seu pensamento físico em suas preocupaçóes mais atuais (64). O terceiro tema é o da sua filosofia do conhecimento, considerada em geral e em sua relaçáo com seu pensamento físico.

Sobre as contribuiçóes de Einstein em física, como sobre seu pensamento dos conceitos, nós tínhamos a escolha, dos primeiros trabalhos sobre a física molecular, sobre a radiaçáo, sobre a eletrodinâmica e a Relatividade restrita, àqueles da maturidade sobre a Relatividade geral, a cosmologia, a teoria do campo unitário. Freqüentemente são opostas as duas séries, como dois períodos distintos e totalmente contrastados de sua atitude em seu trabalho de pesquisador: às preocupaçóes puramente físicas do jovem Einstein, suceder-se-iam aquelas, de natureza mais filosófica e metafísica, do autor da teoria da Relatividade geral convertido a uma concepção da física especulativa e formal, em nome da qual ele se colocou em crítica irredutível da mecânica quântica. As obras de juventude, Relatividade restrita compreendida, que manifestam uma impressionante fecundidade científica nos domínios mais diversos, seriam, segundo esta visão, a obra de um físico mais conforme a norma da disciplina, preocupado antes de tudo em explicar os fenômenos e dar conta das experiências (movimento browniano, efeito fotoelétrico, calores específicos, e até a emissão estimulada - sem esquecer o resultado de Michelson sobre o vento de éter, já mencionado) (65), e, por outro lado, despidas de prejulgamentos filosóficos, até mesmo de preocupações coerentes desta ordem.

Nós escolhemos examinar estas seguintes questóes controversas: para os caminhos da descoberta, a gênese da teoria da Relatividade restrita (66) e, para o pensamento-das significaçóes, os conceitos e os enunciados da Relatividade, restrita e geral. A física quântica fornece igualmente um rico campo de estudos no que diz respeito tanto ao trabalho levando à descoberta quanto à interpretação. Ela é o objeto de uma outra obra, Einstein, les quanta et le réel, que obrigamo-nos a separar desta por razóes de espaço.

A questão da gênese racional da Relatividade restrita é ainda lar- 
gamente aberta, apesar dos numerosos trabalhos históricos sobre o assunto. A análise dos documentos disponíveis, a começar pelo artigo de 1905 o qual, veremos, contém muitos elementos da solução do enigma, e os recursos do estudo comparativo com relaçáo a outros trabalhos vizinhos e praticamente simultâneos (os de Lorentz e Poincaré), revelar-se-áo próprios para nos esclarecer sobre a especificidade da abordagem de Einstein, sobre os traços de seu estilo de pensamento científico que caracteriza sua formulação original dos problemas. Esta conduziu a evidenciar uma dificuldade que ele é o único a designar como tal e que determina o caminho da soluçáo. A recepfão da teoria e sua assimilaçáo veráo preservar apenas a soluçáo sem seu problema, isto é, a nova concepçáo do espaço e do tempo; como se se tinha esquecido que ela interviu apenas - tão revolucionária que ela foi - para resolver um problema anterior, expresso em termos de uma confrontaçáo de princípios teóricos, resultando de uma escolha prioritária destes últimos, e que é antes de tudo a esta formulaçáo que a teoria deve sua origem. Podemos considerar que esta escolha é de natureza metateórica, sob a condição de não esquecer que ela refere-se a princípios que são, eles mesmos, teóricos (no caso, o princípio da relatividade e o da constância da velocidade da luz), e que são consideraçóes físicas que são invocadas para justificá-la (a saber, as proposiçóes da mecânica e do eletromagnetismo que permanecem universalmente válidas apesar das limitaçóes destas teorias). Parece bem difícil separar sem arbítrio, em um raciocínio desta natureza, a teoria e a metateoria, a física e a epistemologia.

Estas condiçốes racionais particulares da gênese da teoria da Relatividade no trabalho de Einstein não são somente circunstanciais: o desenvolvimento ulterior da teoria náo as tornou caducas. As exigências que elas exprimem reconhece-se guiar, efetivamente, tão bem a interpretafaio original que Einstein the deu quanto aquela que foi adotada, geralmente, em seguida. São elas que fazem, precisamente, que se trate de uma teoria da Relatividade, diferentemente das abordagens paralelas de Lorentz e de Poincaré cujos resultados são táo vizinhos e, contudo, tão diferentes quanto à sua significação (abordagens igualmente reveladoras, por outro lado, de escolhas metatebricas, quer dizer, filosóficas no final das contas). Elas preparam além do mais uma etapa ulterior do raciocínio, no sentido da generalizaçáo da teoria.

Tanto quanto, senão mais, do que a solução em termos de espaço e de tempo, este trabalho do pensamento e a escolha efetuada, aparecem plenos de significação, neles mesmos como marca individual ou efeito de estilo, bem como pelo problema objetivo que eles revelam. Pois podemos nos interrogar sobre o alcance desta maneira particular de formular os problemas, que - tanto no caso da relatividade e da teoria 
do campo quanto no da física dos quanta - implica em pensar a relação da teoria física com o seu objeto segundo uma qualificaçăo muito precisa, e que acompanha a preocupaçáo constante para com o que é fundamental. Esta marca do estilo está em correspondência direta com uma filosofia - explicitada mais tarde - que é, essencialmente, pensamento da realidade do mundo e da possibilidade de conhecer esta realidade. Einstein tinha consciência desta dimensão imediatamente filosófica de suas pesquisas, e sua obra, a qual se propóe ir diretamente ao essencial quanto à estrutura profunda da natureza e quanto ao método de pensamento empregado para aí chegar, pode ser vista como uma prática filosofica.

Estando estabelecidos os fatos racionais relativos à descoberta (67), o exame do pensamento de seu autor sobre a significaçáo das estruturas teóricas e conceituais, desta maneira elaboradas ou reorganizadas, ajuda a melhor compreendê-los (68). As duas consideraçóes se sustentam mutuamente sem se confundir, a epistemologia permitindo esclarecer as razóes da história - o desenvolvimento de um processo de pensamento - sem a desnaturar. É igualmente o que resulta do exame, no mesmo espírito, da transformaçáo que se opera no pensamento de Einstein, sobre o objeto destas elaboraçōes teóricas: este objeto passando, depois da reformulaçáo da eletrodinâmica, da covariância para os sistemas de inércia à covariância geral e à dinâmica da gravitaçăo (69).

A teoria da Relatividade geral oferece, com a geometrizaçáo da gravitaçáo, um tema particularmente significativo para a filosofia da ciência, sobre o qual nós nos concentraremos: a questáo da natureza da geometria, isto é, de sua relaçáo com o espaço do mundo físico, aberta desde o conhecimento das geometrias não euclideanas e doravante posta em novos termos. Para compreender o pensamento de Einstein na geometria é necessário situá-lo com relação às idéias e aos debates anteriores, de Gauss e Riemann a Helmholtz e Poincaré. Aqui ainda, o estudo enriquece-se pela abordagem comparativa: nós examinaremos o que $o$ pensamento de Einstein deve às concepçöes destes matemáticos e filósofos, e no que eles diferem, e sua originalidade. Náo podemos, por outro lado, separá-lo do debate sobre a interpretafáno da geometria que mobilizou em seguida os protagonistas das diversas correntes filosóficas, notadamente os neocriticistas e os positivistas e empiristas lógicos, e seus sucessores.

Com estes problemas, nos quais a interpretação das significaçóes ultrapassa o plano estritamente científico e pertence de pleno direito à filosofia, nós encontraremos uma situaçáo de todo modo inversa e complementar à que nós encontramos anteriormente, considerando a ela- 
boraçáo teórica e a descoberta, em que a filosofia impregnava a física. Nós veremos que a física, na realidade de seu processo e no seu conteúdo de significado, não pode ser omissa ou dissociada da análise filosófica das significaçóes gerais feitas a partir de suas proposiçóes formais. Tal pelo menos nos parecerá o fundo do problema da interpretafáno (física da geometria) do qual a abordagem unilateral, por filosofias afastadas da consideração da ciência efetiva, faz esquecer a realidade da construfáo (geométrica da física). O pensamento de Einstein se revela, aqui ainda, como um cadinho no qual se unem estas exigências constitutivas: a interpretação filosófica não pode fazer abstração do conteúdo, ou significado físico, das estruturas teóricas (70).

É ainda um outro nível das relaçōes da física com a filosofia que nós poderíamos abordar em seguida, com a questáo das críticas de Einstein à mecânica quântica, pois que se trata de fato não tanto da própria teoria mas da sua interpretaçáo (71), isto é, da significação (física e filosófica) que convém atribuir a suas proposiçóes. Einstein tinha, ele próprio, largamente contribuído no nascimento e desenvolvimento da física dos quanta, antes dela adquirir seu estatuto de teoria formalizada e autônoma com referência às teorias anteriores, o que ela atingiu próximo de 1927, sob a forma da mecânica quântica. Se cotejamos suas pesquisas na fase construtiva - de 1905, e mesmo antes, até 1925 - e a natureza de suas críticas na fase ulterior, impressionamo-nos pela continuidade de suas preocupaçóes e mesmo pela constância do estilo de sua pesquisa (72). Einstein mostra aí seu cuidado com o caráter fundamental ou não da teoria, e desenvolve consideraçóes e critérios que permitem julgá-la e se pronunciar sobre a interpretaçáo dos conceitos e das proposiçōes teóricas. Ele afirma a necessária autonomia da interpretação física, sempre reclamando da teoria física que ela satisfaça certas exigências teóricas e metateóricas, das quais é útil examinar as características e as relaçôes: um tal exame mostra que elas se apresentam em uma ordem de prioridade na qual o realismo é estritamente requerido, enquanto a questão do determinismo é apenas subseqüente (73).

O que precede deixa ver o sentido no qual nós utilizamos a expressáo a física como prótica filosófica. Não o entendemos, evidentemente, no sentido que a física, segundo Einstein, seria um capítulo da filosofia - mesmo que fosse natural. Isto não é uma definição unívoca da física: outras seriam possíveis que acentuariam outros aspectos diferentes desta ciência, outras maneiras de considerar a natureza de suas proposiçóes, as atividades intelectuais que a elaboram ou a fazem evoluir, ou ainda sua relaçáo com o mundo dos fenômenos, que pode ser muito instrumental. De resto esta expressáo náo seria suficiente para qualificar 
de maneira exata e exaustiva a abordagem de Einstein, e a esgotar tudo isto que representa de específico, de preciso e de técnico, o trabalho em física.

A física como prática filosófica é expressão que quer designar a escolha de um ângulo de abordagem sob o qual é possível perceber certos traços característicos e, cremos nós, fundamentais, da física, e em particular da maneira segundo a qual Einstein trabalhava neste domínio ou pensava seus problemas. Nós o entendemos neste sentido que a física é vivida, até mesmo concebida, também como um exercício filosófico, tanto pelo objetivo que ela se propóe quanto pelo método de discernimento racional que ela emprega, pelo qual ela elabora seus conceitos e enuncia e compreende suas proposiçōes fundamentais. Isto exprime que a física - como as outras ciências - possui um alcance que não perde em nada para as reivindicaçóes mais fortes do projeto de conhecer, que ela tem a vocaçáo de constituir uma imagem do mundo, para tomar os termos do próprio Einstein.

Este olhar filosofico, dirigido aos problemas da física de uma maneira por assim dizer imediata, se faz naturalmente mais e mais consciente. E quando o ato filosófico implícito que é o trabalho científico como busca e como método de pensamento - ao menos no caso que nos ocupa -, se reflete e se percebe como tal, em uma consciência individual que o coloca, encontramo-nos desde então no domínio da filosofia propriamente dita.

A filosofia que o pesquisador foi levado a desenvolver doravante é parte integrante de sua pesquisa, da qual ela tende a exprimir o sentido no mesmo movimento que fez surgir a forma. Isto não confere a suas análises qualquer superioridade sobre aquelas feitas por outros, e nada aliás garante que a perspicácia para os objetos da ciência seja acompanhada de lucidez epistemológica e filosófica comparável. Nós náo estamos obrigados a admitir sem questionar o que os cientistas, mesmo criadores, dizem de sua ciência: relembrando-o, Einstein convidava a examinar os trabalhos próprios dos cientistas em lugar de crer no que dizem quando eles falam de seus métodos (74). Resta que, tendo-o dito, e cada um sendo deixado em sua liberdade, ele náo recusava propor sua própria reflexão sobre a natureza da ciência e do trabalho científico. E nada nos obriga a negligenciar esta reflexáo, e a lhe preferir ensaios mais sistemáticos. Ao contrário: tendo observado o que o físico fazia, e encontrado bastante filosofia neste trabalho, nos interessa muito particularmente saber o que ele pensava quando filosofava no sentido próprio.

Einstein filósofo, isto designa não somente o pensador, criador e 
crítico, da física em sua realidade profunda, mas também o epistemólogo e o filósofo das ciências, formulando, em correlaçáo com seu trabalho sobre os objetos de ciência propriamente ditos, consideraçóes mais gerais sobre a natureza e as condiçóes do conhecimento que procuram explicitar as significaçóes mais essenciais. Pouco depois da elaboração da teoria da Relatividade geral, Einstein começou a exprimir suas concepçóes sobre o conhecimento e suas posiçóes filosóficas, ao mesmo tempo aliás que ele desenvolvia suas análises epistemológicas através do exame crítico dos conceitos e das teorias (suas reflexóes sobre a geometria ocupam, nesta transignio, um importante lugar).

Nós tentaremos em primeiro lugar delimitar seu pércurso epistemológico, isto quer dizer, as etapas do desenvolvimento de seu pensamento-a este respeito e os componentes reflexivos que o constituem. Estes últimos compreendem uma concepçáo das relaçóes entre a ciência e a filosofia, a reflexão sobre sua própria experiência intelectual, o exame das motivaçóes para a busca do conhecimento e a relaçăo deste com a ética. Nós reconheceremos entáo as premissas que condicionam sua filosofia do conhecimento, e que sáo uma definiçáo da inteligibilidade e da verdade, e uma posiçáo com relaçáo ao par antagônico do empírico e do fundamental (75).

Nós examinaremos enfim esta filosofia em si, centrada sobre o essencial: o problema da realidade e de sua representaçáo, a teoria como construçáo levada em direção à primeira. Em torno deste eixo diretor articulam-se as categorias fundamentais do conhecimento, segundo Einstein. Estas são os princípios e os conceitos, que desenham a teoria e carregam seu conteúdo; a unidade e a simplicidade, que resumem seu objetivo e seu método; o real, objeto verdadeiro e último da teoria, mas jamais atingido, e por isto programa e referência; enfim, a completude teórica, conceito eminentemente einsteiniano, que mantém uma ligaçáo estreita com os problemas de significaçăo das proposiçóes e hipostasia no limite assintótico a relaçāo da representaçáo teórica abstrata com o mundo dos fenômenos e do empírico (76).

\section{Notas}

1 N.T. O autor usa o vocábulo sapant para denominar os cientistas referidos, como Descartes, Newton e Einstein, e o vocábulo scientifique como uma forma contemporânea, quando o saber científico requer maior grau de especializaçáo, mas de significado semelhante. A língua portuguesa nāo facilita esta distinção porque subibio ou erudito năo significam sempre claboradores de conhecimentos científicos. Optamos portanto por traduzir tanto supant quanto scientifique por cientista. 
2 Albert Einstein, pbilosopber-scientist, editado por Paul-Arthu Schilpp (conforme Schilpp, 1949). Esta obra faz parte de uma coleção consagrada aos grandes filósofos contemporâneos.

3 Holton, 1967a e b, 1970. Nós retornaremos a este ponto no capítulo VIII. N.T. Mantivemos, na tradução deste primeiro capítulo, as referências a outros capítulos da mesma obra.

4 Feyerabend, 1975. Ver igualmente o capítulo VIII

5 Wiener Kreis, 1929, tr. fr., p. 113,127.

6 Hentschel, 1986; Howard, 1984. Ver os capítulos VII e VIII. Sabemos, por outro lado, que o pensamento de Schlick conheceu dois períodos: somente o primeiro, antes do positivismo lógico, que aqui é referido.

7 Ver, sobre estes últimos, o testemunho de Maria Reichenbach em suas memórias sobre seu marido, in Reichenbach, 1978, v. I, p. 78-86, e em seu prefácio à tradução inglesa de Reichenbach, 1920, aparecida em 1965.

8 "A verdadeira ciência aspira sempre à altura da filosofia, e a verdadeira filosofía não se eleva a năo ser sobre o terreno firme das ciências" escrevia Moritz Schlick (Schlick, $1921 b$ ) a propósito de von Helmholtz e em particular de sua doutrina da geometria (ver os capítulos VI e VII).

9 Synopsis.

10 Reichenbach, 1951 , p. 119.

11 Reichenbach, 1949, p. 291 e 301.

12 Seu texto tem por título precisamente: The philosophical significance of the theory of relativity (Reichenbach, 1949). Trata-se de artigo distinto de outro, de mesmo título, em alemão, aparecido muitos anos antes (Reichenbach, $1922 b$ ).

13 The verifiability theory of meaning (Reichenbach, 1949, p.290-291).

14 Reichenbach, 1949, p. 291: "O físico [se trata efetivamente de Einstein] que queria compreender a experiência de Michelson devia esposar uma filosofia para a qual a significação de um enunciado $e$ redutível à sua possibilidade de verificação." Sobre o verdadeiro papel da experiência de $\mathrm{Mi}$ chelson na gênese da Relatividade, ver o capítulo III.

15 Reichenbach, 1949, p. 291, em seguida à citação da nota precedente: "É este compromisso positivista ou, para melhor dizer, empirista, que determina a posição filos 6 fica de Einstein." Sobre a real posição filosbfica de Einstein em sua juventude, ver o capítulo VIII e, no que diz respeito à Relatividade restrita, os capítulos II a IV.

16 Reichenbach, 1949, p. 291.

17 Ibid, p. 292. 
18 Reichenbach, 1949, p. 292: "A divisão do trabalho entre o físico e o fil6sofo parece bem ser uma consequiencia inevitável da organizaçáo do espirito humano." A crer nisto, o filosofo entregaria, sob este tftulo, exclusivamente ao cientista a capacidade de criar, já que sua própria atitude crítica isto the interditaria (ibid., p. 310). Mais recentemente Paul Feyerabend propos uma dicotomia análoga, mas fundada sobre sua concepção anarquista da criação cientifica, e desta vez em benefficio do cientista contra o filosofo (ver o capítulo Pbilosoply of science persus scientific practice, de Feyerabend, 1981, v. 2, p. 8098).

19 Reichenbach, 1949, p. 292: "Quando em uma certa ocasião, eu perguntei ao Professor Einstein como tinha descoberto a teoria da Relatividade, ele me respondeu que ele o tinha feito porque estava completamente convencido da harmonia do universo." Reichenbach quer crer que poderíamos nos apoiar nesta observação lapidar sobre as motivaçóes conscientes de Einstein, e comenta: "Uma crença nāo é uma filosofia!" Outras análises do pensamento de Einstein (cf. por exemplo, Holton, 1981 c), al se satisfazem igualmente para invocar esta conviç̧ăo como propulsora de sua atividade.

20 Reichenbach, 1949, p. 310.

21 Ibid, p. 293.

22 Reichenbach, 1949, p. 293.

23 Ibia. "Deve ser uma física bem filosbfica, e de maneira eminente, esta que conduziu a tais implicaçōes ...", e "năo e freqüente que se nos apresente sistemas fisicos de uma tal significação filos6fica" (ibid., p. 310).

24 "Definiçōes coordenativas" querendo dizer, na terminologia de Reichenbach, que "elas coordenam um objeto ou um processo fisico a algum conceito fundamental" (Reichenbach, 1949, p. 294). Reichenbach credita a Einstein ter sido o primeiro a analisar sob este ângulo a simultaneidade temporal, o que ele qualifica aliás de "descoberta logica" (ibid ).

25 Reichenbach, 1949, p. 309.

26 Reichenbach, 1949, p. 309-310. Einstein respondeu à análise de Reichenbach no mesmo volume (Einstein, 1949, p. 676-679), opondo a suas concopfóes categóricus argumentos que, precisamente, contestam o empirismo radical afirmado por Reichenbach (ver, sobre este ponto, os capítulos VII, VIII c IX, da presente obra).

27 N.T. Esta segunda parte do artigo foi parcialmente publicada em Nopos Estudos - CEBRAP, 28, 1990, p. 127-36, em tradução de Fernanda Peixoto Massi.

28 Wittgenstein, 1921, p. 4111 e 4112.

29 Wittgenstein, 1921, p. 4112.

30 Cf., por exemplo, Granger, 1968. 
31 Ver também Granger, 1989. Mas, reconhece G. Granger, se a ciência não substitui a filosofia e se a filosofia não produz ciência, existe comunicação entre elas: "A análise filosófica das significaçōes pode levar à posterior constituição de objetos de conhecimento científico".

32 Como escreveu G. Gusdorf: "Inúmeros acontecimentos intelectuais, dentre os mais decisivos, encontram seu domínio de eleição no território de passagem, onde a ciência se quer filosofia e a filosofia se pretende ciência. As inspiraçōes mestras, em estado embrionário, se situam nos limites onde os modos de afirmaçăo da verdade implicam-se mutuamente, antes de qualquer especializaçăo e dissociaçāo" (Gusdorf, 1966, p. 158).

33 Essas "noções de dupla entrada" (científica e filos6fica), como lembra G. Gusdorf, "parecem ter sido constituídas entre a meditação filosófica e a pesquisa científica" (Gusdorf, 1966, p. 153), e possuem origens diversas.

34 Einstein, 1917, p. 14

35 Cassirer, 1921, p. 419.

36 Cassirer, 1921, p. 420 . Sobre o pensamento de Einstein quanto aos conceitos de espaço e de tempo, ver nossos capítulos II e IV.

37 Cf. Granger, 1988.

38 Wartofsky, 1968, p. 16-19. A ontologia, ou a lógica considerada em si mesma, são, por exemplo, aspectos filosóficos exteriores a ciência.

39 Einstein, 1949. Ver nosso capítulo VIII.

40 Sobre a noção de programa epistemológico, ver Paty, 1988 a, capítulo 1.

41 "Em momentos deste gênero, escreve $M$. Wartofsky a esse respeito, o cientista pode muito bem tornar-se, em seu trabalho, filósofo das ciências. Pode fazê-lo mal, se ele é filosoficamente ingênuo ou pouco crítico. Ou pode fazer uma obra filosófica do nível da de Descartes, Newton, Leibniz, Planck ou Einstein, que ajudaram, todos eles, a redesenhar não somente os quadros do pensamento da ciência mas também os conceitos fundamentais da filosofia" (Wartofsky, 1968, p. 19).

42 Koyré, 1961, em sua conferência sobre "Filosofia e Teorias Científicas" (cf. p. 268-269).

43 Porque, nos debates sobre a interpretação física, "são as filosofias que se opóem" (Koyré, ibid. ), o que é exato no caso mencionado da física quântica, que ele menciona, mas que pode dar a idéia de que a atividade científica estaria submetida ao pensamento filosófico. Einstein mesmo indicará como a atividade científica não pode se submeter a uma filosofia sistemática: ver nosso capítulo VIII. Por outro lado, não possó deixar de ser sensível à opiniāo de Koyré, para quem - contra tantas autoridades contrárias - "a interpretação corrente - positivista - de sua obra é completamente inadequada". Isto aparecerá claramente em todos os níveis do presente trabalho. 
44 Ver os discursos relatados por Nathan, Norden, 1960, p. 613, assim como em Cranberg, 1979, p. 9-11. Cf. Paty, 1986 mp. 276.

45 A distinção entre contexto de descoberta e contexto de justificaftro proposta por Reichenbach (1938) foi, em seguida, amplamente aceita. " $A$ epistemologia trata unicamente de construir o contexto de justificaçăo", reafirma Reichenbach em $L$ 'apinement de la plibilosoplie scientifique (1951, p. 6-7).

46 Cf., por exemplo, Kuhn, 1962, e os defensores do relativismo sociológico em história das ciências.

47 O título em alemão da primeira edição de 1935 t na realidade Lógica da pesquisa (Forschung), que virou, na traduçāo inglesa, Lógica da descoberta (discovery) cientffica (Popper, 1935, trad. inglesa aum. 1959. Trad. fr., 1973).

48 Popper, 1935, ed. ingl. 1968, p. 31-32, 40.

49 É esta atenção exclusiva à lógica, e não a uma racionalidade mais ampla, que caracteriza a estreiteza do critério de demarcação popperiana da cientificidade pela refutabilidade ou fulseabilidade.

50 Lakatos, 1970 Æ, 1978.

51 Elie Zahar propós recentemente (Zahar, 1989; ver também Zahar, 1983), na linha de pensamento de Lakatos, uma metodologia mais precisa da heurística dos programas de pesquisa que, fazendo mais jus à precisão histórica, se propóe a reduzir, no trabalho relativo à descoberta, a parte deixada ao irracional. Ele mostra, assim, como, a partir de metaprincípios universalmente aceitos, esse trabalho $\epsilon$, em boa parte, de natureza dedutiva. Sua abordagem, diferente da aqui adotada (ele quer ilustrar uma metodologia, enquanto eu adoto um ponto de vista histórico; ele privilegia o aspecto lógico-dedutivo, enquanto eu tenho uma concepçáo mais fluida de racionalidade), converge entretanto com esta pela afirmaçáo da importância da racionalidade na descoberta. Mas os pontos de partida e os métodos de nossas respectivas análises da teoria da Relatividade săo muito diferentes.

52 É conveniente mencionar aqui um estudo recente de Angelo Maria Petroni (1988) dedicado ao exame de diversos trabalhos sobre a questão da descoberta. Além da obra de Popper - da qual ele observa que suas posiçóes posteriores à Logik der Forscbung, por exemplo, em Objective Krowledge (Popper, 1972), dão mais conta da complexidade dos dados do problema - são as pesquisas de Norwood $R$. Hanson e de Herbert Simon que tratam da possibilidade, ou não, de uma lógica desse processo. A.M. Petroni diagnostica e critica também a reduçáo do problema a uma única logica e invoca a noção mais ampla de racionalidade.

53 Por exemplo, no caso da termodinâmica oú da teoria quântica.

54 Sobre a nopidade em ciência, cf. Paty, 1990, capítulo 1.

55 Ver, por exemplo, Paty, 1986 b. 
56 Sobre a noção de campo de racionalidade, bem como sobre a questāo dos estilos, cf. Paty, 1989, capítulo I.

57 Granger, 1968, ed. 1988. Gilles-G. Granger definiu a noção de estilo como "modalidade de integração do individual no processo concreto que é trabalho" (este último concebido como "dialética efetiva e eficaz de formas e conteúdos", p. 8). O estilo pode ser percebido, nas obras, pelos elementos redundantes (de modo análogo ao que ocorre na linguagem de um individuo), pelo "resíduo não explorado", cuja determinação não depende univocamente da estrutura (objeto do olhar científico); em relaçáo a ela, "o efeito do estilo não é senão a consequiência segunda de um constrangimento de individualizaçāo" (p. 299).

58 Entendo-a no sentido que ela imobiliza e reduz os elementos que considera: sejam proposiçóes acabadas, seja um pensamento criador concebido como puramente subjetivo e irracional.

59 Nesse sentido, Granger fala do cientista como "ator que se apropria praticamente de uma conjuntura" (Granger, 1968, p. 15).

60 O estilo pode ser visto "como um certo modo de introduzir os conceitos de uma teoria, de encadeá-los, unificá-los" e "como uma certa maneira de delimitar a participação intuitiva na determinação desses conceitos" (Granger, 1968, p. 20).

61 Granger nota que "as variações estilísticas correspondem muito geralmente a diferenças de significação" (Granger, 1968. Cf. p. 301-302).

62 A obra já publicada é contudo considerável (ver bibliografia I). Os escritos inéditos, entre os quais uma monumental correspondência, estão reunidos nos Arquivos Einstein (ver o prefácio). Nós fizemos figurar em nossa bibliografia os artigos inéditos mais importantes; as cartas aos correspondentes não publicadas são somente mencionadas nas notas, em funçăo de sua utilização. O primeiro tomo da edição (cronológica) das obras completas de Einstein (compreendendo os inéditos) apareceu quando este trabalho estava em curso, e nós pudemos tê-lo em conta (Einstein, 1987): ele abrange seus anos de juventude e seus primeiros trabalhos (ver em particular nosso capítulo II). Um segundo acaba de aparecer (Einstein, 1990) e numerosos outros seguirão. Ver, por outro lado, a Observação que introduz nossa bibliografia.

63 Estudos parciais sobre tais questôes foram apresentados em Paty, 1979, $1984 b, 1986 a, c$ e $d, 1987 b$.

64 Ver, sobre este ponto, o capítulo VIII.

65 Nestes termos designamos freqüentemente as correspondentes contribuiçōes de Einstein. Mas a explicação (ou a previsão) destes fenómenos foi obtida em realidade como consequiência de abordagens teóricas mais gerais versando sobre as grandezas da termodinâmica e da teoria cinética ou sobre a natureza da radiação (cf. Paty, 1992 a ), ou sobre a eletrodinâmica e o princípio da relatividade (cf. capítulos II e III). 
66 A fisica molecular e a teoria dos quanta poderiam também ser estudadas de maneira análoga (como nós o esboçamos para a segunda, em Einstein, les quanta e le reel, Paty, a ser publicado).

67 Ver o capítulo II.

68 Ver os capítulos III e IV.

69 Ver o capítulo V.

70 O conjunto destas questóes 6 o objeto dos capítulos VI e VII.

71 Cf. Paty (a ser publicado).

72 Ver Einstein, les quanta et le reel (Paty, a ser publicado).

73 Ibid. A ordem de prioridade destas exigências é a seguinte: postulado de uma realidade física existindo independentemente da observaçăo, completude teórica (entendida em certo sentido), caracterizaçăo espaço-temporal desta realidade física, separabilidade e localidade de seus elementos, determinismo. Evidentemente todos estes termos requerem ser definidos $\mathbf{e}$ analisados.

74 Einstein, 1933a.

75 Ver o capítulo VIII.

76 Ver o capítulo IX.

\section{Referências bibliográficas}

BOUVERESSE, Rence (dir.). Karl Popper et la science d'aujourd 'bui. Actes du Colloque de Cerisy, ler - 11 juillet 1981, Paris Aubier, 1989.

CASSIRER, Ernest. Zur Einstein 'schen Relativitaltstheory. Berlin, Bruno Cassirer, 1921. Tr. ingl., Einstein's theory of relativity considered from the epistemological stepoint In: Cassirer, Substance e function e Einstein's theory of relativity. Tr. ingl. por William C. Swabey e Mary C. Swabey, Chicago, Open Court, 1923 (edição utilizada, 1953. New York, Dover). p. 347-460.

CRANBER G, Lawrence. Einstein: amateur scientist. Pbisics Today. dez. 1979, p. 9, 11 .

EINSTEIN, Albert. Ueber die spezielle und die allgemeine Relativitätstheorie, Gemeinperstalndlich. Braunschveig, Vieweg, 1917a (numerosas reediçōes). Tr. ingl. Relativity, the special e general theory, a popular exposition, London, Methuen, 1920.

On the method of theoretical phisics. Oxford, The Herbert Spencer Lecture, 10 junho 1933a; tamberm In: Einstein Albert, Ideas e Opinions, tr. Bergmann Sonja, New York, Crown, 1954 
Reply to criticism. Remarks concerning the essays brought together in this cooperative volume. In: Schilp, 1949c, p. 663-693. [A tradução inglesa foi feita por P.A. Schilpp, cf. seu prefácio, p. XV].

The collected papers of Albert Einstein. Princeton, New Jersey, Princeton University Press, 1987a, v. 1: J. Stachel, D.C. Cassid, R. Schulmann, J. Renn e R. Summerfield (eds.) The early years, 1879-1902, 1987; v. 2: The Swiss years: writings: 1900-1909, 1989.

The collected papers of Albert Einstein. [Tr. ingl. de Einstein, 1987a ], Princeton, New Jersey, Princeton University Press, 1987b; v. 1: The early years, 1879-1902, 1987; v. 2: The Swiss years: writings: 1900-1909, 1989.

FEYERABEND, Paul. Against method (1975). Tr. fr. por Baudouin Jurdant et Agnès Schlumberger, Contre la méthode, esquisse d'une theorie anarchiste de la connaissance. Paris, Seuil, 1979.

Press, 1981.

Philosophical papers. 2 v., Cambridge, Cambridge University

GRANGER, Gilles-Gaston. Essai d une philosophie du style. Paris, Arme Colin, 1968; ed. revista, Paris, Odile Jacob, 1988.

. Pour la connaissance philosophique. Paris, Odile Jacob, 1988.

- Peut-on assigner des frontières à la connaissance scientifique? In: Bouveresse, op.cit., p. 47-61.

GUSDORF, Georges. De l histoire des sciences à $l$ histoire de la penste (Les Sciences humaines et la pensée occidentale, 1). Paris, Payot, 1966.

HENTSCHEL, Klaus. Die Korrespondenz Einstein-Schlick: zum Verhältnis der Physik zur Philosophie. Annals of Science, 43, 1986, p. 475-488.

HOLTON, Gerald. On the origin of the Special Relativity. American Journal of Pbisics, 28, n. 7, jul. 1960, p. 627-636. In: Holton, 1978.

. Poincaré and relativity. In: Mélanges Alexandre Koyré, publiés à l'occasion de son soixante-dixième anniversaire. Paris, Hermann. In: Holton, 1978.

. Où est la réalité? Les réponses d'Einstein [trad. do inglês], Science et synthese, 1967a, p. 97-140.

. Influences on Einstein's early work. American Scholar, 37, inverno $1967 \mathrm{~b}-1968$, p. 59-79.

Mach, Einstein and the search for reality. In: Cohen Robert S. and Seeger R.J.(eds), Ernst mach physicist and philosopher, Dordrecht, Reidel, 1970a, p. 165-199.

. The scientific imagination: case studies. Cambridge, Cambridge University Press, 1978. 
- L imagination scientifique. Tr. do inglês por Jean-François Roberts. Paris, Gallimard, 1981b. [Os artigos traduzidos nāo coincidem com Holton, 1978.]

1981 b, p.130-184.

Aux origines de la relativité restreinte, 1981c. In: Holton,

HOWARD, Don. Realism and conventionalism in Einstein's philosophy of science: the Einstein-Schlick correspondence. Philosopbia Naturalis, $21, \mathrm{n}$. 3-4 (Special issue: Pbilosophy of science, History of Science), 1984, p. 616629.

KOYRE, Alexere. Etudes a bistoire de la pensée pbilosopbique, 1961. Cabiers des Annales. Paris, Arme Colin, 1961; réed., Paris, Gallimard, 1971.

KUHN, Thomas. The structure of scientific revolutions, 1962; $2^{2}$ ed. ampliada. Chicago, University of Chicago Press, 1970.

LAKATOS, Imre. Falsification and the methodology of scientific research programmes. In Lakatos, Imre and Musgrave, Alan (eds.), Criticism and the growth of knowledge. Proceedings of the International Colloquium in the PhiLosophy of Science. London, 1965, v. 4, Cambridge, Cambridge University Press, 1970a, p. 91-196.

Philosophical papers, v.l: The methodology of scientific research programmes. John Worrall e Gregory Currie (eds.), Cambridge, Cambridge University Press, 1978.

NATHAN, Otto \& NORDEN, Heinz (eds.). Einstein on peace. New York, Simon \& Schuster, 1960.

PATY, Michel. Einstein et la philosophie en France: à propos du séjour de 1922. Cabiers Fundamenta Scientiae, n.93, 1979b, p.23-41; também no Bulletin de la Socifte francaise de physique, n.35, nouvelle série, janvier 1980, p.9-12; e La Pensée, n.210, février 1980, p.3-11.

. Einstein, Albert (1879-1955). In Denis Huisman (dir.), Dictionaire des philosophes, PUF, v. 1, 1984b, p. 831-837.

. Einstein e Spinoza, 1986c. In Marjorie Grene e Debra Nails (eds.), Spinoza and the sciences, Dordrecht, Reidel, 1986, p. 267-302. [O original em francés foi publicado em duas partes: La doctrine du parallélisme de Spinoza et le programme épistemologique d'Einstein, Cabiers Spinozn, Paris, Ed. Réplique, n. 5, hiver 1984-1985, p. 93-108; e Einstein et Spinoza. In Renée Bouveresse (dir.), Spinoza, science et religion, Institut interdisciplinaire d'etudes épistémologiques, Lyon, et Paris, Vrin, 1988, p. 183-207].

. Einstein, sa vie, sa pensée (Einstein actuel ou dépassé?), 1986c. Ciència e Cultura, São Paulo, 38, n. 4, abr. 1986, p. 614-628.

- Einstein et l'arme atomique: la responasabilité des scientifiques,

1986d. La Penste, n. 250, mars-avril 1986, p. 51-62. 
Einstein et la penste de Newton, 1987b. La Pensée, n. 259,

. La matière dérobée, 1988a. L'appropriation critique de l'objet de la phisique contemporaine. Paris, Archives contemporaines, 1988.

Physical Geometry and Special Relativity: Einstein and Poincart, in Luciano Boi, Dominique Flament et Jean-Michel Salanski (eds.), Colloque international 1830-1930: un siecle de geometrie, de C.F. Gauss et B. Reimann à $H$. Poincark et E. Cartan. Epistemologie, histoire et mathtmatiques. Paris, 18-23 september 1989, Atas a aparecer, Springer Verlag. - (a aparecer) Einstein, les quanta et le rél, 1992a.

PETRONI, Angelo Maria. Sur quelques positions récentes relatives à la logique de la découverte scientifique. Etudes philosophiques, 1988, n. 4, p. 459-474.

POPPER, Karl R. Logik der Forschung. Zur Erkentnisstheorie der modernen Naturnoissenschaft. Wien, Springer Verlag, 1935; reed. com ampliaçōes em 1959, 1968. Tr. ingl. The logic of scientific discovery, 1959, 1968.

don Press, 1972.

REICHENBACH, Hans. Relativitätstheorie und Erkenntnis a-priori. Berlin, Springer, 1920, Tr. ingl. por Maria Reichenbach, The theory of relativity and a-priori knowledge. Berkeley, University of California Press, 1965.

. La signification philosophique de la théorie de la relativité, Repue philosophique de la France et de l'Etranger, 94, 1922b, p. 5-61.

1938.

- Experience and prediction, Chicago, University of Chicago Press,

. The philosophical significance of the theory of Reiativity, in Schilpp, 1949, p. 289-311 [Apesar da identidade dos títulos este texto de 1949 é totalmente diferente de outro datado de $1922 b$.].

Press, 1951; reed. 1973.

The rise of scientific philosophy. Berkeley, University of California

. Selected writings. Ed. por Robert S.Cohen e Maria Reichenbach, 2 v., Dordrecht, Reidel, 1978.

SCHILPP, Paul Arthur. Albert Einstein, philosopher-scientist. The library of living philosophers, La Salle (IIl.), Open Court, 1949; reed.; ibid. e London, Cambridge University Press, 3a ed., 1970.

SCHLICK, Moritz. Helmholtz als Erkenntnistheoretiker [Conferência pelo centenário de Helmholtz], 1921 b, in Helmboltz als Physiker, Physiolog und Philosoph, Karlsruhe, 1922, p. 29-39. Tr. ingl., in Schlick, Philosophical papers, ed. por H.L. Mulder e B.F.B. van de Velde-Schlick; tr. por P. Heath, 
W. Sellars, H. Feigl e M. Brodbeck, 2 v., Dordrecht, Reidel, 1979, v. 1, p. 335-342.

WARTOFSKY, Marx. Conceptual foundations of scientific thought. An introduction to the philosoply of science. London, MacMillan, 1968.

WIENER Kreis. Wissenschaftlische Weltauflassung: der Wrene Krois, Wien, A.Wolf, 1929. Republicado in Neurath, Wissenchaftliche Weltauflassung, Sozialismus und logische Empirimus, ed. por R. Hegselmann, Frankfurt, Suhrkamp, 1979, p. 81-101.

WITTGENSTENN, Ludwig. Logisch-Philosophische Abhandlung, in Annalen der Naturphilosopbie. Tr. ingl. por D.F. Pears e B.F. McGuiness, Tractatus logico-pbilosopbicus. London, Routledge \& Kegan Paul, 1961.

ZAHAR. Logic of discovery or psychology of invention? The British Journal for the Philosoplby of Science, 34, 1983.

Court, 1989.

Einstein's revolution. A study in beuristics. La Salle (IIl.), Open

\section{Resumo}

$A$ fisica, como próticu filosofica, designa a escolha de ângulo de abordagem sob o qual 6 possivel perceber caracteristicas fundamentais da fisica. Assumimos que os papéis do físico e do filósofo não são tão demarcados e que a tarefa do físico $\epsilon$ inseparavelmente enunciar a significaçăo dos conceitos, estabelecendo sua identificação lógico-matemática, c ligá-los à experiência. Nesta perspectiva, a análise da atividade de Einstein, especialmente o exame da gênese da teoria da Relatividade restrita e das significaçōes nos conceitos e enunciados da Relatividade restrita e geral nos leva à afirmaçāo da tese expressa no epíteto Einstein filbsofo. Para este percurso foi necessário então a crítica da corrente filosb́fica Círculo de Viena - aparentemente mais próxima da atividade einsteniana, mas que só o tomou como referência na condição de físico. Em especial ć analisada, e recusada, a tese de Reichenbach da separaçáo entre o contexto de justificativa - ao qual se aplica a análise filos6fica - e o contexto de descoberta - relegado exclusivamente ao campo da psicologia. Para esta crítica buscamos, nos processos de descoberta, náo uma rígida estrutura lógica mas a noçáo mais ampla de racionalidade.

\section{Abstract}

Physics as pbilosopbical practice points out the option of an approach which enables us to perceive fundamental features of physics. We maintain that the physicist and the philosopher play roles not so disjuncted and that the physicist's task is as much to enunciate the meaning of the concepts, establishing its logical and mathematic identification, as to link them to experience. With this point of view we analyze Einstein's activity with emphasis on the rise of Special Relativity Theory and the meaning of the concepts of Special and General Relativity. This analysis carries us to the thesis expressed in the title Einstein, philosopher. To this way we have needed to criticize that philosophical movement - Vienna's Circle - which was apparently the nearest one to Einstein's 
activity. However the Vienna's Circle only took him as physicist but not as philosopher. We analyze, and criticize, in particular Reichenbach's thesis on the separation between the context of justification and the context of discovery, this last one being left to the psychological camp. Through this criticism, we are looking, in discovery procedures, not a rigid logical structure but the larger notion of rationality.

Michel Paty é diretor de pesquisa do Centro Nacional de Pesquisa Científica (CNRS), da França e da Université Paris VII e chefe da equipe Rehseis (Recherches Épistémologiques et Historiques sus les Sciences Exactes et les Institutions Scientifiques) do CNRS.

Este texto é o primeiro capítulo de seu livro Einstein Pbilosophe - La physique comme pratique philosoplique, editado este ano pela Presses Universitaires de France. As principais idéias do livro foram expostas e debatidas $\mathrm{em}$ aulas e seminários no Departamento de Filosofia da USP e, especialmente, no Instituto de Estudos Avançados (IEA), onde o autor coordenou, em 1990, um ciclo de debates sobre "Ciência e filosofia", ministrando três seminários sobre "Einstein, física, matemática e filosofia". Neste texto, as chàmadas aos capítulos referem-se ao livro.

O original em francês - "Einstein, savant et philosophe" - encontra-se à disposição do leitor no IEA para eventual consulta.

Tradução de Olival Freire Jr., professor do Instituto de Física da UFBa. Revista pelo autor. 